\title{
MEASURING TECHNICAL EFFICIENCY OF INSURANCE COMPANIES USING DYNAMIC NETWORK DEA: AN INTERMEDIATION APPROACH
}

\author{
Mohammad NOURANI ${ }^{*}$, Evelyn Shyamala DEVADASON, VGR CHANDRAN \\ Faculty of Economics and Administration, University of Malaya, Jalan Universiti, \\ 50603 Kuala Lumpur, Malaysia
}

Received 07 March 2016; accepted 04 March 2017

\begin{abstract}
This study measures technical efficiency of the Malaysian insurance companies using a new framework for performance efficiency, built on the intermediation approach, by decomposing the complex service processes of insurance companies into two functional divisions, premium accumulation and investment capability. The study employs a dynamic network data envelopment analysis for performance evaluation of insurer (life, general and composite insurers) and ownership (local and foreign) types, spanning the period 2007-2014. The findings reveal a lack of efficiency in the investment capability function among local insurers as compared to their foreign counterparts. While the composite or non-specialized segment performs better in the investment capability function, the general segment achieves better efficiency in the premium accumulation function. The results suggest the high usage of input quantities and lack of total investment as key reasons for low efficiency, particularly among the local insurers. Implications for business excellence for insurance companies are further discussed.
\end{abstract}

Keywords: performance evaluation, data envelopment analysis, intermediation approach, dynamic network slacks-based measure, insurance companies.

JEL Classification: G22, L25.

\section{Introduction}

In the context of performance efficiency using the data envelopment analysis (DEA) approach, the important question on the true measure of production mechanism for insurance companies remains vague (Brockett et al. 2005). There are two theoretical streams to evaluate the efficiency of an insurance company, namely the production approach and the financial intermediary approach (Brockett et al. 2004). Under the production approach, the role of financial institutions is confined to that of service providers to account hold-

*Corresponding author. E-mail: mohammad@nourani.net

This is an Open Access article distributed under the terms of the Creative Commons Attribution License (http://creativecommons. org/licenses/by/4.0/), which permits unrestricted use, distribution, and reproduction in any medium, provided the original author and source are credited. 
ers, while in the intermediation approach, financial institutions act to channel the funds between savers and investors. Berger and Humphrey (1997) differentiate between the two approaches in identifying how to measure the performance of financial services. The production approach is found to be suitable for evaluating financial branches or subsidiaries, while the intermediation approach is more appropriate for evaluating the entire financial industry (Berger, Humphrey 1997; Brockett et al. 2004).

The current insurance literature has given more emphasis on the use of the production approach, which is more appropriate for evaluating the performance of manufacturing companies (Chen et al. 2011; Cummins, Rubio-Misas 2006; Cummins et al. 2010; Cummins, Xie 2008; Eling, Luhnen 2010b; Kuo et al. 2017; Lu et al. 2014; Nourani et al. 2017), while the application of the intermediation approach has not received much attention in insurance-related studies. Additionally, although recent research has increasingly focused on the empirical evaluation of insurance efficiency, recent studies have largely adopted traditional measures of efficiency evaluation (Biener, Eling 2012; Cummins et al. 2010; Huang et al. 2012; Huang, Eling 2013; Xie 2010); therefore, a consistent conclusion remains elusive. The traditional DEA assumes a service process as a single black box that transforms inputs to outputs. However, more than one stage may be involved in completing a service process. Therefore, by using the traditional DEA approach, we are in fact neglecting the internal linking of activities between different stages or divisions, and thereby neglecting the decomposed inefficiencies of each stage. As such, the multi-stage DEA approach, introduced to open up black boxes, is needed to address the issue of efficiency (Färe et al. 2007) as it identifies the source(s) of inefficiency in the whole service process. In this respect, one may overestimate or underestimate the efficiency scores if a proper technique is not applied. In fact, an accurate measure of performance measurement is a preliminary step to achieve business excellence within any financial or non-financial entity.

This study builds on the use of the financial intermediation approach in line with Brockett et al. (2005) and proposes a new framework for insurance companies to assess their performance, which is supported by an extant theory on insurance literature. Following which, the results of this study provide useful input on resource allocation and strategic decision-making for insurance companies. The remainder of this study unfolds as follows: Section 1 details the proposed new framework for measuring insurance efficiency. Section 2 describes the research design. Section 3 discusses the research findings, and the final section concludes the study.

\section{Proposed insurance efficiency framework}

\subsection{The service process for insurance}

The traditional performance assessment framework for insurance companies is rooted in the production process of manufacturing systems. Unlike manufacturing, insurance reflects a special type of service process (Müller 1981). Pfeffer and Klock (1974: 3) define insurance as follows: Insurance is a device for the reduction of uncertainty of one party, called the insured, through the transfer of particular risks to another party, called the insurer, who 
offers a restoration, at least in part, of economic losses suffered by the insured. The contemplation of this definition highlights the fundamental function of an insurance company; the reduction of risks through some transfer mechanisms. The concept of risk transfer is a theoretical phenomenon, it is not operational or practical to the needs of an insurance company (Müller 1981). In fact, an important deduction of the insurance definition lies in the process where risk transfer occurs. It is not a convincing argument for insureds to assume a certain amount of premium in exchange for the transfer of risks, but rather to explain what is taking place during the risk transfer mechanism. The process of operationalizing an insurance company covers economic losses (Pfeffer, Klock 1974), and the flow of money into the insurance system from premium contributors and from the insurance system to claimants (Trowbridge 1975). An insurance company favours the money transfer definition of insurance arrangement (Müller 1981). The flow of money in the insurance system requires the regeneration of money through investment.

Here, the concept of service process of an insurance company relates to the entire spectrum of business activities. There are a number of theories underlying the service process of an insurance company. The production theory for an insurance company provides a shallow picture of insurance activities, given its non-material nature. The contribution of actuarial sciences to insurance can provide provisional risk estimation and forecasting, yet the service process is bounded to probability distributions and stochastic processes (Müller 1981). The financial portfolio theory for an insurance company views the activity of an insurer as a "levered investment operation" that borrows funds, by issuing risky obligations (premium accumulation) and investing part of these funds in securities (Biger, Kahane 1978; Doherty 1980). Relying on the same theoretical concept, Haugen and Kroncke (1970) considers an insurance company as a financial intermediary that generates capital by selling a diversified portfolio of insurance claims (capital generating opportunities), and invests the funds in a balanced portfolio of financial instruments (investment opportunities). Likewise, MacMinn and Witt (1987) forwards that an insurance company has to make two decisions; the first decision involves the number of policies to sell pertaining to the underwriting activities to accumulate premiums, and the second involves, how to invest these generated funds in an investment portfolio to yield highest profits.

While the "levered investment operation" view of an insurance company has received criticism $^{1}$, it appears to be the most rational perspective. In fact, for a firm-level analysis of cash flow activities, the insurance company is viewed as a financial intermediary that aims to maximize profits. Figure 1 shows the flow of funds in an insurance company. It revisits the insurance cash flow activities as a financial intermediary entity (Brockett et al. 2004, 2005), and allows us to capture the financial cash flow of an insurer as a fund receiver and a fund investor chronologically.

Based on the discussion above, the following sections define the key functions of the service process and emphasizes the important role of the time dimension for the analysis.

\footnotetext{
${ }^{1}$ It is argued that the insurance activities are reduced to decision on financial operations (Müller 1981). However, in the same article, Müller (1981) stated that there is no definite approach to define the input-output process and organizational arrangement for insurance processes.
} 


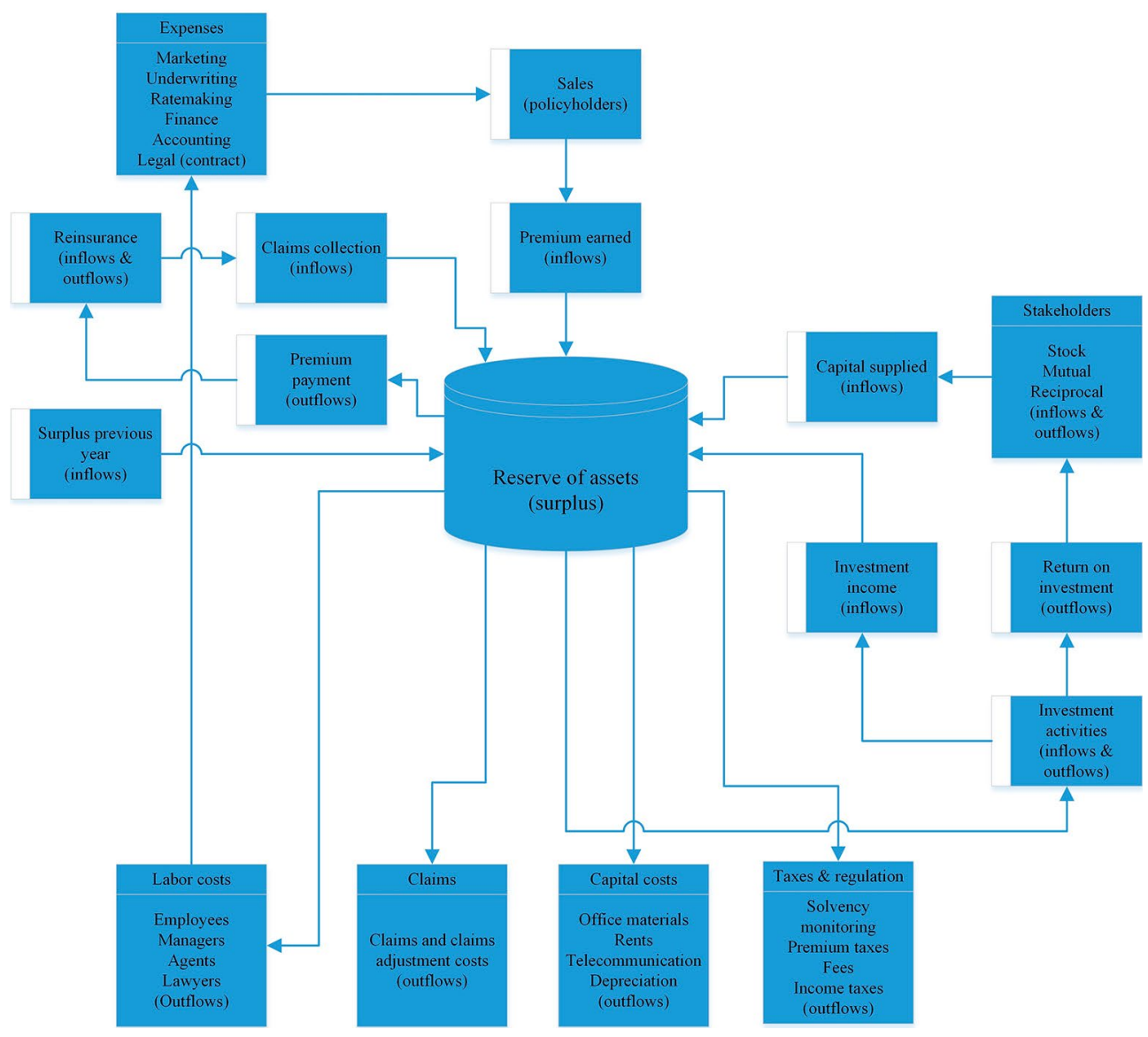

Figure 1. Insurance cash flow as a financial intermediary (source: retrieved and modified from Brockett et al. 2005, 2004)

\subsection{Core service functions}

The first stage involves activities to accumulate and/or generate funds, which is the premium accumulation function. Being a financial intermediary entity, an insurance company issues contingent claims to policyholders. More precisely, insurers borrow money from policyholders to feed the reserve of assets. Ultimately, a part of the borrowed funds will be returned to the claimants as the costs of claims. As shown in Figure 1, these activities provide inflows and outflows into the reserve within the premium accumulation function.

The second involves investment activities of an insurance company, which is the investment capability function. An insurance company uses a part of the capital accumulated from policyholders (premiums) and stakeholders (capital supplied) to purchase a portfolio of assets. A higher insurance capital provides more security for policyholders in terms of compensation in the event of losses. 


\subsection{Time dimension}

Von Lanzenauer and Wright (1977) pointed out that there is a need to explicitly model the interactions in insurance activities in a dynamic manner because the stationary condition is rather a weak assumption. While the study by Müller (1981) implicitly discussed the time dimension in the insurance information model, the literature, to date, has not discoursed the issue of time dimension in the context of service processes of insurance companies. Particularly, there are some input factors within the service process that may not produce any effects within the postulated time. In short, there is a lag effect for these factors in the service process. These input factors are so called carry-over inputs (Tone, Tsutsui 2010). The service process of an insurance company often is evaluated in a static nature without much consideration given to the time dynamics. Hence, it is important to incorporate the evolutionary perspective (time dimension) into the service processes of insurance companies.

\section{Research design}

\subsection{Performance evaluation in insurance}

Performance evaluation has progressively become a reliable measure of business excellence. Nowadays, various business enterprises, including insurance companies, utilize the frontier efficiency analysis because a performance measurement technique has to deliver enough information to link up with business strategies, whereas, the single-dimensional ratio analysis such as profit or cost evaluation techniques lack inferential ability. In the literature, two primary methodologies have been used by insurance studies to estimate efficient frontiers: econometric or parametric approach, and mathematical programming or nonparametric approach. While both approaches have their own advantages and disadvantages, nonparametric methods, in particular the DEA, are highly popular among insurance studies (Eling, Luhnen 2010b).

Efficiency-related studies using the DEA technique among insurance companies can be traced back to the early 1990s (Bjurek et al. 1990; Mahajan 1991; Fecher, Pestieau 1993; Cummins et al. 1996, Cummins, Zi 1998, Cummins et al. 1999). There are also recent attempts to measure the efficiency of insurance companies (for example, Huang et al. 2012; Huang, Eling 2013; Barros, Wanke 2014; Barros et al. 2014; Kweh et al. 2014a, 2014b; Kuo et al. 2017; Barros, Wanke 2015, 2016; Wanke, Barros 2016), but insurance-related studies remain limited relative to research on other financial institutions. The study by Liu et al. (2013) on DEA application in research published between 1978 and 2010 show that only 44 (1.4 percent) papers focused on insurance companies, whereas 323 (10.3 percent) papers were related to the banking sector. The need for research on insurance efficiency is of fundamental importance, as the insurance sector has the potentials to contribute to economic growth (Arena 2008).

Apart from the dearth of literature on insurance, limitations also prevail in the models employed to measure performance. The traditional frontier efficiency models, including conventional DEA models, are unable to detail the sources of inefficiency (Wu et al. 2016). 
For example, insurers use assets and expenditures to generate premiums, and then premiums are meant to be utilized for investments plans. The premiums play a dual role in the whole service process. In the first stage, premiums are the outputs, and then become the inputs in the second stage. The first stage outputs are the intermediate measures of service processes that link the two stages (Färe, Whittaker 1995). Instead, the multi-stage DEA approaches, or so called network DEA (NDEA), open up black boxes to provide detailed efficiency measures about what happens inside them (Färe et al. 2007). Hence, the multistage efficiency approach is now becoming popular in insurance-related research.

To date, the DEA literature on insurance has also focused largely on the dynamic aspect (Kweh et al. 2014a; Wanke et al. 2015, 2016) or the network aspect (Kao, Hwang 2008). However, the vibrant and complex service processes of insurance companies demand the consideration of both structures in efficiency evaluation. In this study, both structures are considered as the two service functions of insurance companies require a network structure, connected through intermediate measures, and the time dimension, in turn, requires the linking of activities or carry-over factors, to explain the dynamic nature of businesses. To this end, the service process of an insurance company, as the form of an underlying dynamic network DEA (DN-DEA) problem, requires the identification of input, intermediate, carry-over and output factors.

\subsection{Choice of input and output factors}

An important step in performance evaluation is identifying the contributing factors. This issue is particularly critical for a service sector such as insurance, as opposed to manufacturing sectors where physical resources produce physical products. Generally, the resources used in a service process are the inputs, and the outcomes are the outputs (Zhu 2014: 1). There are three main insurance inputs, labor, business services and materials, and capital (Brockett et al. 2005, 2004; Cummins, Weiss 2013). The selection of output quantities relates to the service processes of insurance companies. The production approach uses the value of losses incurred as an output (Cummins et al. 1999). However, Brockett et al. (2005, 2004) asserted that the inclusion of incurred losses as output, counters the general notion of efficiency.

The dynamic network process combined with the financial intermediation approach in this study provide a better understanding of insurance activities, as illustrated in Figure 2 . In the first stage, an insurer accumulates premiums by utilizing the inputs that are commonly used by both production and financial intermediary approaches (Brockett et al. 2005, 2004; Cummins, Weiss 2013). This study utilizes labor and business service expenses, equity capital and debt capital as the inputs for the premium accumulation function. Brockett et al. $(2005,2004)$ used the owners' stake or equity of the previous year for the DEA analysis. The reason for this is the lag effect of equity capital in the service process of an insurance company. Hence, this study includes equity capital as the carry-over input in the first stage. The utilized inputs in the first stage produce the net earned premium (positive) and net claims (negative). These two factors are intermediate items, since these are also the input factors for the second stage. The aim of second stage is to gain profit and add value to the business through investment activities. Therefore, the investment stage uses two in- 


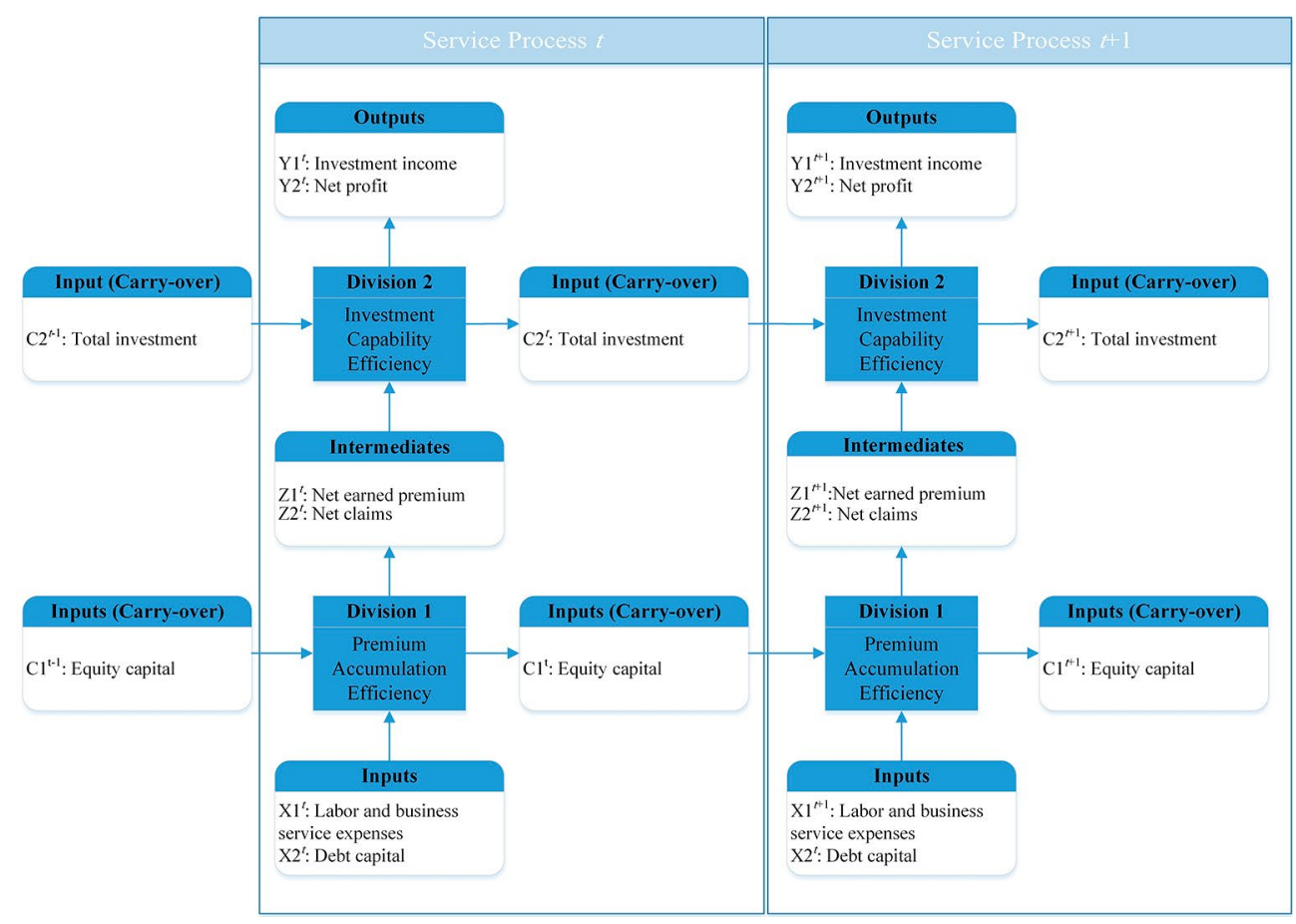

Figure 2. Dynamic network insurance efficiency framework

termediate factors along with total investment, which are accumulated from previous year insurance activities, to produce the two final outputs, investment income and net profit. It is worth noting that total investment is an input quantity, which one cannot except to see its immediate effect in achieving the profit/loss for an insurance company. Subsequently, this study includes total investment as carry-over item in the second stage. Table 1 provides the summary of the variables used in the dynamic network insurance efficiency framework.

\subsection{Preliminary requirements of DEA}

First, the decision-making units (DMUs) of a DEA analysis must fulfil the homogeneity assumption. Farrell (1957) proposes that the evaluation results is significant only when the DMUs are homogenous. Considering that DMUs of a DEA model must possess identical attributes, similar objectives and same market conditions (Golany, Roll 1989), this study only selects conventional insurance companies publicly traded in the Malaysian market as the DMUs. Further, all insurance companies, including life, composite and general, are considered similar in operating the two functions, premium accumulation and investment capability.

Second, the minimum number of DMUs must follow a rule prior to the DEA analysis. According to Golany and Roll (1989), the number of DMUs should be at least twice the number of input and output factors. In this study, there are 31 DMUs and this satisfies the requirement for the minimum number of DEA in the two stages [i.e., $31>2 \times(4+2+2)$ ]. 
Table 1. Definitions of input, carry-over, intermediate and output variables

\begin{tabular}{|c|c|c|c|c|}
\hline Variable & Symbol & Definition & Literature & Source \\
\hline \multicolumn{5}{|c|}{ Inputs } \\
\hline $\begin{array}{l}\text { Labor and } \\
\text { business } \\
\text { service } \\
\text { expenses }\end{array}$ & $\mathrm{X} 1$ & $\begin{array}{l}\text { The total amount of labor and business service } \\
\text { expenses including employee benefit expenses } \\
\text { and key management personnel compensation } \\
\text { for the year. }\end{array}$ & $\begin{array}{l}\text { (Eling, } \\
\text { Luhnen } \\
\text { 2010a) }\end{array}$ & $\begin{array}{l}\text { Income } \\
\text { statement }\end{array}$ \\
\hline Debt capital & $\mathrm{X} 2$ & $\begin{array}{l}\text { The total amount of insurance contract liabilities, } \\
\text { financial liabilities, insurance payables and tax } \\
\text { liabilities of the year. }\end{array}$ & $\begin{array}{l}\text { (Brockett } \\
\text { et al. } 2005 \text {, } \\
\text { 2004) }\end{array}$ & $\begin{array}{l}\text { Balance } \\
\text { sheet }\end{array}$ \\
\hline \multicolumn{5}{|c|}{ Carry-over inputs } \\
\hline $\begin{array}{l}\text { Equity } \\
\text { capital }\end{array}$ & $\mathrm{C} 1$ & $\begin{array}{l}\text { The total amount of shareholders' equities } \\
\text { including share capital, retained earnings and } \\
\text { other reserves at the beginning of the year. }\end{array}$ & $\begin{array}{l}\text { (Brockett } \\
\text { et al. } 2005 \text {, } \\
\text { 2004) }\end{array}$ & $\begin{array}{l}\text { Balance } \\
\text { sheet }\end{array}$ \\
\hline $\begin{array}{l}\text { Total } \\
\text { investment }\end{array}$ & $\mathrm{C} 2$ & $\begin{array}{l}\text { The total amount of all government and non- } \\
\text { government securities and other investments of } \\
\text { an insurance company at the beginning of the } \\
\text { year. }\end{array}$ & $\begin{array}{l}\text { (Brockett } \\
\text { et al. } 2005 \text {, } \\
\text { 2004) }\end{array}$ & $\begin{array}{l}\text { Balance } \\
\text { sheet }\end{array}$ \\
\hline \multicolumn{5}{|c|}{ Intermediate inputs/outputs } \\
\hline $\begin{array}{l}\text { Net earned } \\
\text { premiums }\end{array}$ & $\mathrm{Z1}$ & $\begin{array}{l}\text { The total amount of gross earned premiums } \\
\text { minus premiums ceded to reinsurers for the year. }\end{array}$ & $\begin{array}{l}\text { (Kao, Hwang } \\
\text { 2008) }\end{array}$ & $\begin{array}{l}\text { Income } \\
\text { statement }\end{array}$ \\
\hline Net claims & $\mathrm{Z} 2$ & $\begin{array}{l}\text { The total amount of gross benefits and claims } \\
\text { paid minus the claims ceded to reinsurers for the } \\
\text { year. }\end{array}$ & $\begin{array}{l}\text { (Brockett } \\
\text { et al. } 2005 \text {, } \\
\text { 2004) } \\
\end{array}$ & $\begin{array}{l}\text { Income } \\
\text { statement }\end{array}$ \\
\hline \multicolumn{5}{|c|}{ Outputs } \\
\hline $\begin{array}{l}\text { Investment } \\
\text { income }\end{array}$ & Y1 & $\begin{array}{l}\text { The total amount of generated income from all } \\
\text { the investment activities for the year. }\end{array}$ & $\begin{array}{l}\text { (Brockett } \\
\text { et al. } 2005 \text {, } \\
\text { 2004) }\end{array}$ & $\begin{array}{l}\text { Income } \\
\text { statement }\end{array}$ \\
\hline Net profit & $\mathrm{Y} 2$ & $\begin{array}{l}\text { The total amount of income after deducting all } \\
\text { the operating and tax expenses for the year. }\end{array}$ & $\begin{array}{l}\text { (Kao, Hwang } \\
\text { 2008) }\end{array}$ & $\begin{array}{l}\text { Income } \\
\text { statement }\end{array}$ \\
\hline
\end{tabular}

Note: Compiled from the literature.

Third, the DEA analysis requires "isotonic" assumption, meaning that input and output factors should have positive correlation (Golany, Roll 1989). More specifically, a proportional increase in an input variable should result in a proportional increase in an output variable. Based on the Spearman's rho correlation test reported in Table 2, significant positive relationships exist between the input and output factors. This result satisfies the isotonic assumption. Thus, the developed DN-DEA framework is considered to hold high construct validity.

\subsection{Model specification of DN-DEA}

A DEA model provides the efficiency scores as well as the frontier projections, based on slack values for inefficient DMUs. In doing so, the selected model defines the reference set for inefficient DMUs; then they have to follow a certain efficient DMU in order to become efficient units. There are two types of efficiency measure models, namely radial and nonradial. Each model type provides a unique result and suggestion for inefficient units. 
Table 2. Spearman's rho correlation coefficients

\begin{tabular}{ccccccccc}
\hline Variable & $\mathrm{X} 1$ & $\mathrm{X} 2$ & $\mathrm{Z} 1$ & $\mathrm{Z} 2$ & $\mathrm{C} 1$ & $\mathrm{C} 2$ & $\mathrm{Y} 1$ & $\mathrm{Y} 2$ \\
\hline $\mathrm{X} 1$ & 1.000 & & & & & & & \\
\hline $\mathrm{X} 2$ & $0.737^{* *}$ & 1.000 & & & & & & \\
\hline $\mathrm{Z} 1$ & $0.832^{* *}$ & $0.875^{* *}$ & 1.000 & & & & & \\
\hline $\mathrm{Z} 2$ & $0.835^{* *}$ & $0.894^{* *}$ & $0.892^{* *}$ & 1.000 & & & & \\
\hline $\mathrm{C} 1$ & $0.808^{* *}$ & $0.592^{* *}$ & $0.688^{* *}$ & $0.652^{* *}$ & 1.000 & & & \\
\hline $\mathrm{C} 2$ & $0.722^{* *}$ & $0.873^{* *}$ & $0.763^{* *}$ & $0.862^{* *}$ & $0.603^{* *}$ & 1.000 & & \\
\hline $\mathrm{Y} 1$ & $0.784^{* *}$ & $0.903^{* *}$ & $0.809^{* *}$ & $0.908^{* *}$ & $0.636^{* *}$ & $0.954^{* *}$ & 1.000 & \\
\hline $\mathrm{Y} 2$ & $0.750^{* *}$ & $0.619^{* *}$ & $0.688^{* *}$ & $0.654^{* *}$ & $0.788^{* *}$ & $0.577^{* *}$ & $0.612^{* *}$ & 1.000 \\
\hline
\end{tabular}

Notes: (1) Refer to Table 1 for definition of variables. ${ }^{* *}$ Significant at the 0.01 level (2-tailed) and *significant at the 0.05 level (2-tailed).

The Charnes, Cooper and Rhodes (CCR) model (Charnes et al. 1978) is the basis for the radial approach, and the slacks-based measure (SBM) model (Tone 2001) represents the non-radial approach. While radial models neglect the non-radial input and output slacks, non-radial models overlook the radial characteristics of inputs and outputs, if any (Cooper et al. 2007: 89). Radial models may lack objectivity in terms of reflecting the real input/output conditions for each organization, and stand on the assumption that inputs or outputs undergo proportional changes (Wu et al. 2016). Non-radial models, on the other hand, which deal directly with the input excesses and the output shortfalls and do not change proportionally, may achieve results that are more realistic. The changing nature of operational preferences of companies in today's business world makes the choice of the non-radial approach more relevant (Avkiran 2009). Hence, this study measures the efficiency of insurance companies using the non-radial approach. For this purpose, the SBM model is considered a reliable non-radial measure.

Tone and Tsutsui $(2010,2009)$ introduced the network SBM and the dynamic SBM model in which both models account for slacks when measuring efficiency. Combining both models, Tone and Tsutsui (2014) formalized the dynamic DEA with network structure and named it as the dynamic network slack-based measure (DNSBM). As pointed out by Tone and Tsutsui (2014), this model takes into account multiple divisions linked to intermediate activities of the network structure at each period of time (vertically) and connects the network structure through carry-over activities among two following periods (horizontally). In fact, the blend of two structures, dynamic and network, provide a more comprehensive analysis, whereby both divisional and periodical interactions are considered simultaneously. Hence, this study selects the DNSBM model to measure the efficiency of insurance companies.

\subsubsection{Objective function}

There are three main objective functions to follow, input-oriented, output-oriented and non-oriented (Cooper et al. 2007: 115). The input-oriented approach targets to minimize input quantities, while satisfying at least the given level of output quantities. On the contrary, the output-oriented approach aims to maximize output quantities, while maintaining the 
observed level of input consumption. The third approach, non-oriented, deals with input excesses and output shortfalls at the same time in order to maximize both. The choice of objective function will determine the projection path to the envelope surface by which a DEA analyst can suggest the area of improvements in both inputs and outputs. Whether to choose the input-, output- or non-oriented approach depends on the service process that characterizes the company's operation. For the purpose of the insurance efficiency framework, the objective is to identify both over-utilization of input quantities and shortage of output quantities. Therefore, the non-oriented approach for the objective function is chosen.

\subsubsection{Production technology}

The envelopment surface, which defines the production possibility set (PPS), will differ depending on the scale assumptions relevant to the production technology. Two general scale assumptions exist: constant returns to scale (CRS) and variable returns to scale (VRS). CRS refers to the proportional changes of inputs and outputs, while the VRS does not assume such proportional changes. There is a need for rendering reasonable care when choosing a return to scale type, though the identification will not be an easy one since DEA is a data oriented and non-parametric technique. Cooper et al. (2007: 334) suggest "if the data set includes numeric values with a large difference in magnitude, the VRS model may be a choice. However, if the data set consists of normalized numbers, the CRS model might be an appropriate candidate". The VRS is chosen to offset the possible influence of different scales of inputs and outputs on efficiency. Following Lu et al. (2016), this study also conducted statistical tests between the efficiency scores under CRS and VRS technologies for the two stages. The unreported results support the use of VRS technology.

\subsubsection{DNSBM model}

This study selects the non-oriented, VRS, DNSBM model to evaluate the efficiency of insurance companies. As suggested by Cooper et al. (2007), this study runs the efficiency analysis with the help of DEA SolverPro ${ }^{\text {TM }}$ V.11 developed by SAITECH, which encompasses all the new models including the DNSBM. The DNSBM formulation proposed by Tone and Tsutsui (2014) is as follows:

Consider the dynamic network processes presented in Figure 2 that deal with $n$ insurers $(j=1, \ldots, n)$, consisting of $k$ divisions $(k=1, \ldots, K)$ over $T$ terms $(t=1, \ldots, T)$. At each term, insurers have common $m_{k}$ inputs $\left(i=1, \ldots, m_{k}\right), q$ link variables $(p=1, \ldots, q)$, $r_{k}$ outputs $\left(h=1, \ldots, r_{k}\right)$ and $c_{k}\left(w=1, \ldots, c_{k}\right)$ carry-overs from period $t-1$ to period $t$ consisting of $k$ divisions. Let $x_{i j t}^{t}, y_{h j k}^{t}$ and $v_{p j k}^{t(b-g)}$ denote the input, output, and link from division $b$ to division $g$ values of insurer $j$ consisting of $k$ divisions at term $t$, respectively. $z_{w j k}^{t, t+1}$ denotes the continuity of link flows (carry-overs) between terms $t$ and $t+1$. This study defines the non-oriented efficiency by solving the program as follows: 


$$
\phi_{o}=\operatorname{Min} \frac{\frac{1}{T} \sum_{t=1}^{T} \frac{1}{K} \sum_{k=1}^{K}\left[1-\frac{1}{m_{k}+c_{k}+q}\left(\sum_{i=1}^{m} \frac{s_{i o t}^{k^{-}}}{x_{i o t}^{k}}+\sum_{p=1}^{q} \frac{s_{p o}^{t-}}{v_{p o}^{t(b-g)}}+\sum_{w=1}^{c_{k}} \frac{s_{w o k}^{t, t+1}}{x_{i o t}^{k}}\right)\right]}{\frac{1}{T} \sum_{t=1}^{T} \frac{1}{K} \sum_{k=1}^{K}\left[1+\frac{1}{r_{k}+q}\left(\sum_{h=1}^{r_{k}} \frac{s_{h o t}^{k^{+}}}{y_{h o t}^{k}}+\sum_{p=1}^{q} \frac{s_{p o}^{t+}}{v_{p o}^{t(b-g)}}\right)\right]}
$$

s.t.

$$
\begin{aligned}
& x_{i o t}^{k}=\sum_{j=1}^{n} x_{i j t}^{k} \lambda_{j t}^{k}+s_{i o t}^{k^{-}},\left(i=1, \ldots, m_{k} ; k=1, \ldots, K ; t=1, \ldots, T\right), \\
& y_{h o t}^{k}=\sum_{j=1}^{n} y_{h j t}^{k} \lambda_{j t}^{k}-s_{h o t}^{k^{+}}, \quad\left(h=1, \ldots, r_{k} ; k=1, \ldots, K ; t=1, \ldots, T\right), \\
& \sum_{j=1}^{n} \lambda_{j t}^{k}=1, \quad(k=1, \ldots, K ; t=1, \ldots, T), \\
& v_{p o}^{t(b-g)} \lambda_{j t}^{g}=\sum_{j=1}^{n} v_{p j}^{t(b-g)} \lambda_{j t}^{b}+s_{p o}^{t-}, \forall(b, g)(t=1, \ldots, T ; p=1, \ldots, q), \\
& v_{p o}^{t(b-g)} \lambda_{j t}^{g}=\sum_{j=1}^{n} v_{p j}^{t(b-g)} \lambda_{j t}^{b}-s_{p o}^{t+}, \forall(b, g)(t=1, \ldots, T ; p=1, \ldots, q), \\
& z_{w o k}^{t, t+1}=\sum_{j=1}^{n} z_{w j k}^{t, t+1} \lambda_{j t}^{k}+s_{w o k}^{t, t+1}\left(w=1, \ldots, c_{k} ; t=1, \ldots, T ; k=1, \ldots, K\right), \\
& \lambda_{j t}^{k} \geq 0, s_{i o t}^{k^{-}} \geq 0, s_{h o t}^{k^{+}} \geq 0, s_{p o}^{t-} \geq 0, s_{p o}^{t+} \geq 0, s_{w o k}^{t, t+1} \geq 0,
\end{aligned}
$$

where $s_{i o t}^{k^{-}}$and $s_{\text {hot }}^{k^{+}}$are, respectively input/output slacks, $s_{p o}^{t-}$ and $s_{p o}^{t+}$ are, respectively as-input/as-output link slacks, $s_{\text {wok }}^{t, t+1}$ is carry-over excess slacks. (4) suggests that the constructed best practice frontier exhibits VRS technology at stage. (5) points that the linking activities are treated as input to the succeeding division and excesses are accounted for in the input inefficiency. (6) presents that the linking activities are treated as output from the preceding division and shortages are accounted for in the output inefficiency. (7) shows that the carry-overs are treated as inputs and their values are restricted to be not greater than the observed ones. Comparative excess in carry-overs is accounted as inefficiency. The production possibility set for the objective $D M U_{o}(o=1, \ldots, n)$ is expressed by (2), (3), (4), (5), (6) and (7).

Let an optimal solution (1) subject to (2), (3), (4), (5), (6) and (7) be

$$
\begin{aligned}
& \left\{\lambda_{j t}^{k^{*}}, j=1, \ldots, n ; s_{i o t}^{k^{*}}, i=1, \ldots, m_{k} ; s_{h o t}^{k^{+^{*}}}, h=1, \ldots, r_{k} ; s_{p o}^{t-*}, s_{p o}^{t+^{*}},\right. \\
& \left.p=1, \ldots, q ; s_{w o k}^{t, t+1}, w=1, \ldots, c_{k} ; k=1, \ldots, K, t=1, \ldots, T\right\} .
\end{aligned}
$$

The non-oriented overall efficiency during the term $T$ for the objective $D M U_{o}$ can be defined by

$$
=\frac{\frac{1}{T} \sum_{t=1}^{T} \frac{1}{K} \sum_{k=1}^{K}\left[1-\frac{1}{m_{k}+c_{k}+q}\left(\sum_{i=1}^{m_{k}} \frac{s_{i o t}^{k^{-*}}}{x_{i o t}^{k}}+\sum_{p=1}^{q} \frac{s_{p o}^{t-*}}{v_{p o}^{t(b-g)}}+\sum_{w=1}^{c_{k}} \frac{s_{w o k}^{t, t+1^{*}}}{x_{i o t}^{k}}\right)\right]}{\frac{1}{T} \sum_{t=1}^{T} \frac{1}{K} \sum_{k=1}^{K}\left[1+\frac{1}{r_{k}+q}\left(\sum_{h=1}^{r_{k}} \frac{s_{h o t}^{k^{+*}}}{y_{h o t}^{k}}+\sum_{p=1}^{q} \frac{s_{p o}^{t+*}}{v_{p o}^{t(b-g)}}\right)\right]} .
$$


This objective function (8) is an extension of the non-oriented SBM model (Tone 2001) and deals with excesses in both input resources and undesirable (bad) links. The numerator is the average input efficiency and the denominator is the inverse of the average output efficiency. This study defines the non-oriented overall efficiency as a ratio that ranges between 0 and 1 , and attains 1 when all slacks are zero. This objective function value is also units-invariant.

Period efficiency is defined for the objective $D M U_{o}$ by

$$
\pi_{o}^{t^{*}}=\frac{\frac{1}{K} \sum_{k=1}^{K}\left[1-\frac{1}{m_{k}+c_{k}+q}\left(\sum_{i=1}^{m} \frac{s_{i o t}^{k^{-*}}}{x_{i o t}^{k}}+\sum_{p=1}^{q} \frac{s_{p o}^{t-*}}{v_{p o}^{t(b-g)}}+\sum_{w=1}^{c_{k}} \frac{s_{w o k}^{t, t+1^{*}}}{x_{i o t}^{k}}\right)\right]}{\frac{1}{K} \sum_{k=1}^{K}\left[1+\frac{1}{r_{k}+q}\left(\sum_{h=1}^{r_{k}} \frac{s_{h o t}^{k^{+*}}}{y_{h o t}^{k}}+\sum_{p=1}^{q} \frac{s_{p o}^{t+*}}{v_{p o}^{t(b-g)}}\right)\right]},(\forall t) .
$$

Divisional efficiency for the objective $D M U_{o}$ is defined by

$$
\eta_{o}^{k^{*}}=\frac{\frac{1}{T} \sum_{t=1}^{T}\left[1-\frac{1}{m_{k}+c_{k}+q}\left(\sum_{i=1}^{m} \frac{s_{i o t}^{k^{*}}}{x_{i o t}^{k}}+\sum_{p=1}^{q} \frac{s_{p o}^{t-*}}{v_{p o}^{t(b-g)}}+\sum_{w=1}^{c_{k}} \frac{s_{w o k}^{t, t+1^{*}}}{x_{i o t}^{k}}\right)\right]}{\frac{1}{T} \sum_{t=1}^{T}\left[1+\frac{1}{r_{k}+q}\left(\sum_{h=1}^{r_{k}} \frac{s_{h o t}^{k^{+*}}}{y_{h o t}^{k}}+\sum_{p=1}^{q} \frac{s_{p o}^{t+*}}{v_{p o}^{t(b-g)}}\right)\right]},(\forall k) .
$$

Period-divisional efficiency (premium accumulation efficiency or investment capability efficiency at time $t$ ) for the objective $D M U_{o}$ is defined by

$$
\varphi_{k o}^{t^{*}}=\frac{\left[1-\frac{1}{m_{k}+c_{k}+q}\left(\sum_{i=1}^{m} \frac{s_{i o t}^{k^{*}}}{x_{i o t}^{k}}+\sum_{p=1}^{q} \frac{s_{p o}^{t-*}}{v_{p o}^{t(b-g)}}+\sum_{w=1}^{c_{k}} \frac{s_{w o k}^{t, t+1^{*}}}{x_{i o t}^{k}}\right)\right]}{\left[1+\frac{1}{r_{k}+q}\left(\sum_{h=1}^{r_{k}} \frac{s_{h o t}^{k^{+*}}}{y_{h o t}^{k}}+\sum_{p=1}^{q} \frac{s_{p o}^{t+*}}{v_{p o}^{t(b-g)}}\right)\right]},(\forall k, t) .
$$

The projection of a target insurer is defined by

$$
\begin{aligned}
& \hat{x}_{i o t}^{k}=x_{i o t}^{k}-s_{i o t}^{k-}\left(i=1, \ldots, m_{k} ; k=1, \ldots, K ; t=1, \ldots, T\right), \\
& \hat{y}_{h o k}^{t}=y_{h o k}^{t}+s_{h o k}^{t+}\left(h=1, \ldots, r_{k} ; k=1, \ldots, K ; t=1, \ldots, T\right), \\
& \hat{v}_{p o}^{t(b-g)}=v_{p o}^{t(b-g)}+s_{p o}^{t+} \forall(b, g)(t=1, \ldots, T ; p=1, \ldots, q), \\
& \hat{z}_{\text {wok }}^{t, t+1}=z_{\text {wok }}^{t, t+1}-s_{\text {wok }}^{t, t+1}\left(w=1, \ldots, c_{k} ; t=1, \ldots, T ; k=1, \ldots, K\right) .
\end{aligned}
$$

\subsection{Data description}

The efficiency analysis requires firm-level data of insurance companies. The firm-level data for this study is compiled from annual reports of publicly-traded insurance companies in Malaysia, including companies in general insurance segment, life insurance segment and life and general insurance segment (composite or non-specialized). As of 2014, there are 
33 insurers operating in the Malaysian insurance sector. After excluding the insurers with missing values, a total of 31 insurers were selected; 19 general insurers, 9 life insurers and 5 composite insurers. The data covers 8 years, 2007-2014. Given the lag effect of carry-over items, the sample is made up of 217 observations. The total net premiums earned by the 31 companies constitute 98 percent of the total, suggesting that the sample is representative of the Malaysian insurance sector.

Table 3 presents the summary statistics of the sample. There is significant variation in the data, which indicates the differences in the operating scales of the sampled insurers. The large differences across insurers also justify the use of unit-invariant in the efficiency analysis (Du et al. 2014). For more details on yearly statistics, see Appendix Table A1.

Table 3. Summary statistics of the input, carry-over, intermediate, and output variables

\begin{tabular}{cccccccc}
\hline Variable & Mean & Median & SD & CV & Range & Skewness & N \\
\hline X1 & 107835 & 70115 & 99281 & 0.92 & 622892 & 2.15 & 217 \\
\hline $\mathrm{X} 2$ & 4395794 & 1181206 & 9646814 & 2.19 & 58952778 & 4.07 & 217 \\
\hline $\mathrm{C} 1$ & 829592 & 394831 & 1221174 & 1.47 & 6332665 & 2.90 & 217 \\
\hline $\mathrm{C} 2$ & 735913 & 269531 & 1279446 & 1.74 & 7952759 & 3.41 & 217 \\
\hline $\mathrm{Z} 1$ & 511809 & 306143 & 520414 & 1.02 & 3612709 & 2.52 & 217 \\
\hline $\mathrm{Z} 2$ & 3995068 & 953953 & 8830321 & 2.21 & 57429577 & 4.13 & 217 \\
\hline $\mathrm{Y} 1$ & 198029 & 53411 & 409743 & 2.07 & 2439690 & 3.71 & 217 \\
\hline $\mathrm{Y} 2$ & 98078 & 45309 & 144014 & 1.47 & 986693 & 2.38 & 217 \\
\hline
\end{tabular}

Notes: (1) Refer to Table 1 for definition of variables; (2) SD: standard deviation; CV: coefficient of variation $(\mathrm{SD} / \mathrm{mean})$.

\section{Research findings}

\subsection{Efficiency analysis}

Table 4 reports the overall efficiency scores of insurers. The findings suggest that specialized insurers achieved higher overall efficiency, on average, at 82.86 percent for life insurers and 79.72 percent for general insurers, as compared to composite or non-specialized insurers at 77.67. The overall efficiency of general insurers consistently surpassed that of the life and composite segments, while the latter two witnessed fluctuations in their efficiency scores. However, the efficiency scores for life insurers remained above the sectoral average, and vice versa for general insurers.

To statistically examine if differences exist between the insurance-type, life, general and composite, as well as ownership-type, foreign and local, this study utilizes the Kruskal-Wallis test. This non-parametric test shows that overall efficiency does not differ across company type (Table 7). The non-significant result may suggest that the insurance companies are homogenous, and thus supports the homogeneity requirement for the DEA analysis. However, an opening up of the black box will enable us to reveal some finer differences among them. The same result does not hold for ownership type. The overall efficiency scores for foreign insurers' are found to be higher than that of local insurers, and also of the total average, suggesting the strength of foreign players in the local market. 
Table 4. Overall efficiency scores for Malaysian insurers

\begin{tabular}{|c|c|c|c|c|c|c|c|c|c|c|}
\hline Insurer & Ownership & Rank & 2008 & 2009 & 2010 & 2011 & 2012 & 2013 & 2014 & Average \\
\hline \multicolumn{11}{|c|}{ General Insurers } \\
\hline $\begin{array}{l}\text { Allianz General } \\
\text { Insurance Co. } \\
\text { Bhd }\end{array}$ & F & 9 & 0.9287 & 0.9998 & 0.9999 & 0.9116 & 0.9999 & 0.9998 & 0.9999 & 0.9762 \\
\hline $\begin{array}{l}\text { AmGeneral } \\
\text { Insurance Bhd }\end{array}$ & $\mathrm{L}$ & 13 & 1 & 0.5665 & 0.7733 & 0.7435 & 0.9053 & 0.9999 & 0.9998 & 0.8233 \\
\hline $\begin{array}{l}\text { AXA Affin } \\
\text { General } \\
\text { Insurance Bhd }\end{array}$ & $\mathrm{L}$ & 29 & 0.4886 & 0.4665 & 0.5726 & 0.5808 & 0.6977 & 0.6317 & 0.7295 & 0.5843 \\
\hline $\begin{array}{l}\text { Berjaya Sompo } \\
\text { Insurance Bhd }\end{array}$ & $\mathrm{L}$ & 28 & 0.5191 & 0.4766 & 0.5278 & 0.6871 & 0.7056 & 0.7046 & 0.7482 & 0.6092 \\
\hline $\begin{array}{l}\text { AIG Malaysia } \\
\text { Insurance Bhd }\end{array}$ & $\mathrm{F}$ & 12 & 0.5935 & 0.7806 & 0.9047 & 0.8288 & 0.9351 & 1 & 0.9204 & 0.8316 \\
\hline $\begin{array}{l}\text { Lonpac } \\
\text { Insurance } \\
\text { Berhad }\end{array}$ & $\mathrm{L}$ & 7 & 0.9122 & 1 & 1 & 1 & 1 & 1 & 1 & 0.9875 \\
\hline $\begin{array}{l}\text { MSIG Insurance } \\
\text { Bhd }\end{array}$ & $\mathrm{F}$ & 4 & 1 & 0.9983 & 0.9998 & 0.9999 & 0.9999 & 0.9999 & 0.9999 & 0.9997 \\
\hline $\begin{array}{l}\text { Multi-Purpose } \\
\text { Insurans Bhd }\end{array}$ & $\mathrm{L}$ & 24 & 0.5242 & 0.5409 & 0.7617 & 0.7271 & 0.739 & 0.6856 & 0.7449 & 0.6618 \\
\hline $\begin{array}{l}\text { Overseas } \\
\text { Assurance } \\
\text { Corporation } \\
\text { Bhd }\end{array}$ & $\mathrm{F}$ & 11 & 0.675 & 0.7158 & 0.9056 & 1 & 0.9577 & 0.8357 & 1 & 0.8524 \\
\hline $\begin{array}{l}\text { Tune Insurance } \\
\text { Malaysia Bhd }\end{array}$ & $\mathrm{L}$ & 16 & 0.6834 & 0.7652 & 0.7558 & 0.8554 & 0.8964 & 0.8321 & 0.8815 & 0.8022 \\
\hline $\begin{array}{l}\text { Pacific \& Orient } \\
\text { Insurance Co. } \\
\text { Bhd }\end{array}$ & $\mathrm{L}$ & 26 & 0.5216 & 0.5803 & 0.6248 & 0.7244 & 0.6907 & 0.6743 & 0.7498 & 0.6442 \\
\hline $\begin{array}{l}\text { The Pacific } \\
\text { Insurance Bhd }\end{array}$ & $\mathrm{F}$ & 15 & 0.648 & 0.7392 & 0.7653 & 0.8379 & 0.8922 & 0.9013 & 1 & 0.8115 \\
\hline $\begin{array}{l}\text { Progressive } \\
\text { Insurance Bhd }\end{array}$ & $\mathrm{L}$ & 1 & 1 & 1 & 1 & 1 & 1 & 1 & 1 & 1 \\
\hline $\begin{array}{l}\text { QBE Insurance } \\
\text { Bhd }\end{array}$ & $\mathrm{F}$ & 3 & 0.9992 & 1 & 1 & 1 & 1 & 1 & 1 & 0.9999 \\
\hline $\begin{array}{l}\text { RHB Insurance } \\
\text { Bhd }\end{array}$ & $\mathrm{L}$ & 18 & 0.6151 & 0.6826 & 0.7638 & 0.795 & 0.8091 & 0.7562 & 0.9086 & 0.7528 \\
\hline $\begin{array}{l}\text { Tokio Marine } \\
\text { Insurans Bhd }\end{array}$ & $\mathrm{F}$ & 25 & 0.4258 & 0.5591 & 0.6357 & 0.7236 & 0.7397 & 0.774 & 0.8089 & 0.6443 \\
\hline $\begin{array}{l}\text { Uni.Asia } \\
\text { General } \\
\text { Insurance Bhd }\end{array}$ & $\mathrm{L}$ & 31 & 0.4448 & 0.4234 & 0.4676 & 0.6655 & 0.7605 & 0.7365 & 0.7512 & 0.5718 \\
\hline \multicolumn{11}{|c|}{ Composite Insurers } \\
\hline AIA Bhd & $\mathrm{F}$ & 6 & 1 & 1 & 0.9999 & 0.9235 & 0.9998 & 1 & 1 & 0.9890 \\
\hline $\begin{array}{l}\text { Etiqa Insurance } \\
\text { Bhd }\end{array}$ & $\mathrm{L}$ & 23 & 0.4053 & 0.6155 & 0.8343 & 0.8633 & 0.8719 & 0.8334 & 0.8322 & 0.6921 \\
\hline
\end{tabular}


End of Table 4

\begin{tabular}{|c|c|c|c|c|c|c|c|c|c|c|}
\hline Insurer & Ownership & Rank & 2008 & 2009 & 2010 & 2011 & 2012 & 2013 & 2014 & Average \\
\hline $\begin{array}{l}\text { MCIS Insurance } \\
\text { Bhd }\end{array}$ & $\mathrm{L}$ & 27 & 0.8298 & 0.3505 & 0.6921 & 0.6064 & 0.7145 & 0.7306 & 0.7225 & 0.6194 \\
\hline $\begin{array}{l}\text { Prudential } \\
\text { Assurance } \\
\text { Malaysia Bhd }\end{array}$ & $\mathrm{F}$ & 5 & 0.9960 & 1 & 1 & 1 & 1 & 1 & 1 & 0.9994 \\
\hline $\begin{array}{l}\text { Zurich } \\
\text { Insurance } \\
\text { Malaysia Berhad }\end{array}$ & $\mathrm{F}$ & 30 & 0.2841 & 0.6918 & 0.6283 & 0.8371 & 0.6703 & 0.7568 & 0.7058 & 0.5838 \\
\hline
\end{tabular}

\begin{tabular}{|c|c|c|c|c|c|c|c|c|c|c|}
\hline \multicolumn{11}{|c|}{ Life Insurers } \\
\hline $\begin{array}{l}\text { Insurance } \\
\text { Malaysia Bhd }\end{array}$ & $\mathrm{F}$ & 22 & 0.7733 & 0.7329 & 0.6904 & 0.5968 & 0.8026 & 0.7668 & 0.7455 & 0.7237 \\
\hline $\begin{array}{l}\text { AmMetLife } \\
\text { insurance Bhd }\end{array}$ & $\mathrm{L}$ & 14 & 0.8915 & 0.7625 & 0.7911 & 0.6706 & 0.8745 & 1 & 0.8464 & 0.8225 \\
\hline $\begin{array}{l}\text { AXA Affin Life } \\
\text { Insurance Bhd }\end{array}$ & $\mathrm{L}$ & 19 & 1 & 0.6422 & 0.6867 & 0.7373 & 0.6772 & 0.7909 & 0.7195 & 0.7397 \\
\hline $\begin{array}{l}\text { Sun Life } \\
\text { Malaysia } \\
\text { Assurance Bhd }\end{array}$ & $\mathrm{L}$ & 17 & 0.5079 & 0.7791 & 0.7037 & 0.9268 & 0.8774 & 0.9114 & 0.9233 & 0.7786 \\
\hline $\begin{array}{l}\text { Great Eastern } \\
\text { Life Assurance } \\
\text { Bhd }\end{array}$ & $\mathrm{F}$ & 1 & 1 & 1 & 1 & 1 & 1 & 1 & 1 & 1 \\
\hline $\begin{array}{l}\text { Hong Leong } \\
\text { Assurance Bhd }\end{array}$ & $\mathrm{L}$ & 10 & 0.8303 & 1 & 1 & 1 & 1 & 1 & 0.8976 & 0.9589 \\
\hline $\begin{array}{l}\text { Manulife } \\
\text { Insurance Bhd }\end{array}$ & $\mathrm{F}$ & 21 & 0.4857 & 0.8871 & 0.8736 & 0.8323 & 0.7699 & 0.7134 & 0.7095 & 0.7253 \\
\hline $\begin{array}{l}\text { Tokio Marine } \\
\text { Life Insurance } \\
\text { Bhd }\end{array}$ & $\mathrm{F}$ & 20 & 0.8731 & 0.8427 & 0.8012 & 0.5629 & 0.7099 & 0.6849 & 0.7099 & 0.7286 \\
\hline $\begin{array}{l}\text { Gibraltar BSN } \\
\text { Life Bhd }\end{array}$ & $\mathrm{L}$ & 8 & 0.8738 & 1 & 1 & 1 & 1 & 1 & 1 & 0.9798 \\
\hline Average & & & 0.7332 & 0.7613 & 0.8116 & 0.8270 & 0.8612 & 0.8619 & 0.8727 & 0.8030 \\
\hline Average Foreign & & & 0.7630 & 0.8534 & 0.8717 & 0.8610 & 0.8912 & 0.8880 & 0.9000 & 0.8475 \\
\hline Average Local & & & 0.7087 & 0.6854 & 0.7621 & 0.7990 & 0.8365 & 0.8404 & 0.8503 & 0.7664 \\
\hline Average General & & & 0.7047 & 0.7232 & 0.7917 & 0.8283 & 0.8664 & 0.8548 & 0.8966 & 0.7972 \\
\hline $\begin{array}{l}\text { Average } \\
\text { Composite }\end{array}$ & & & 0.7030 & 0.7316 & 0.8309 & 0.8461 & 0.8513 & 0.8642 & 0.8521 & 0.7767 \\
\hline Average Life & & & 0.8040 & 0.8496 & 0.8385 & 0.8141 & 0.8568 & 0.8742 & 0.8391 & 0.8286 \\
\hline Max & & & 1 & 1 & 1 & 1 & 1 & 1 & 1 & 1 \\
\hline Min & & & 0.2841 & 0.3505 & 0.4676 & 0.5629 & 0.6703 & 0.6317 & 0.7058 & 0.5718 \\
\hline $\mathrm{SD}$ & & & 0.2281 & 0.2044 & 0.1633 & 0.1469 & 0.1240 & 0.1327 & 0.1201 & 0.1506 \\
\hline No. efficient & & & 6 & 8 & 7 & 8 & 7 & 10 & 9 & 2 \\
\hline
\end{tabular}

Notes: $\mathrm{F}$ - foreign; L - local. 
The Kruskal-Wallis test further confirms that significant differences exist between the overall efficiency scores of foreign and local insurers at the 1 percent significant level (Table 7). Foreign insurers are able to better utilize resources given their technological advancement (Huang et al. 2012), and quality of services (Choi, Elyasiani 2011). In this regard, policymakers should encourage learning and understanding of the best practices of the foreign insurers among the local insurers.

Based on yearly average scores, only local insurers became more inefficient in 2009 with the implementation of some liberalization measures in the sector. In fact, most insurers experienced increases in efficiency scores in the aftermath of the 2009 financial liberalization policy and the 2008-2009 global financial crisis. Progressive Insurance Bhd, with a long history of operation in Malaysia, is the only general insurer that gained an efficiency score of one for all the years, while the Great Eastern Life Assurance Bhd, a Singaporean based company and the biggest insurance company in terms of total assets, achieved full overall efficiency among the life insurance segment.

The disaggregated insurance efficiency scores into premium accumulation and investment capability are presented in Table 5 and Table 6, respectively. It is apparent that the main driver of overall efficiency in the Malaysian insurance sector is premium accumulation. In other words, the Malaysian insurance companies appear to be more efficient in terms of accumulating premiums (89.58\%) rather than in investment strategies $(78.80 \%)$. This finding holds true for both foreign and local insurers.

Table 5. Premium accumulation efficiency scores for Malaysian insurers

\begin{tabular}{|c|c|c|c|c|c|c|c|c|c|c|}
\hline Insurer & Ownership & Rank & 2008 & 2009 & 2010 & 2011 & 2012 & 2013 & 2014 & Average \\
\hline \multicolumn{11}{|c|}{ General Insurers } \\
\hline $\begin{array}{l}\text { Allianz General } \\
\text { Insurance Co. } \\
\text { Bhd }\end{array}$ & $\mathrm{F}$ & 9 & 0.8579 & 0.9999 & 0.9999 & 0.9999 & 0.9999 & 0.9999 & 1 & 0.9796 \\
\hline $\begin{array}{l}\text { AmGeneral } \\
\text { Insurance Bhd }\end{array}$ & $\mathrm{L}$ & 11 & 1 & 1 & 1 & 0.8489 & 0.9948 & 1 & 1 & 0.9777 \\
\hline $\begin{array}{l}\text { AXA Affin } \\
\text { General } \\
\text { Insurance Bhd }\end{array}$ & $\mathrm{L}$ & 21 & 0.7467 & 0.8071 & 0.776 & 0.9248 & 0.9878 & 0.9286 & 0.9284 & 0.8713 \\
\hline $\begin{array}{l}\text { Berjaya Sompo } \\
\text { Insurance Bhd }\end{array}$ & $\mathrm{L}$ & 19 & 0.6635 & 0.7116 & 0.996 & 1 & 1 & 0.9634 & 0.9989 & 0.9048 \\
\hline $\begin{array}{l}\text { AIG Malaysia } \\
\text { Insurance Bhd }\end{array}$ & $\mathrm{F}$ & 20 & 0.5672 & 0.877 & 0.9387 & 0.9358 & 1 & 1 & 1 & 0.9027 \\
\hline $\begin{array}{l}\text { Lonpac } \\
\text { Insurance } \\
\text { Berhad }\end{array}$ & $\mathrm{L}$ & 13 & 0.8244 & 1 & 1 & 1 & 1 & 1 & 1 & 0.9749 \\
\hline $\begin{array}{l}\text { MSIG Insurance } \\
\text { Bhd }\end{array}$ & $\mathrm{F}$ & 1 & 1 & 1 & 1 & 1 & 1 & 1 & 1 & 1 \\
\hline $\begin{array}{l}\text { Multi-Purpose } \\
\text { Insurans Bhd }\end{array}$ & $\mathrm{L}$ & 28 & 0.588 & 0.6959 & 0.7722 & 0.819 & 0.8049 & 0.727 & 0.7977 & 0.7435 \\
\hline $\begin{array}{l}\text { Overseas } \\
\text { Assurance } \\
\text { Corporation Bhd }\end{array}$ & $\mathrm{F}$ & 16 & 0.8862 & 1 & 0.9559 & 1 & 0.9156 & 0.8806 & 1 & 0.9483 \\
\hline
\end{tabular}


Continue of Table 5

\begin{tabular}{|c|c|c|c|c|c|c|c|c|c|c|}
\hline Insurer & Ownership & Rank & 2008 & 2009 & 2010 & 2011 & 2012 & 2013 & 2014 & Average \\
\hline $\begin{array}{l}\text { Tune Insurance } \\
\text { Malaysia Bhd }\end{array}$ & $\mathrm{L}$ & 18 & 1 & 1 & 1 & 1 & 1 & 0.707 & 0.7811 & 0.9269 \\
\hline $\begin{array}{l}\text { Pacific \& Orient } \\
\text { Insurance Co. } \\
\text { Bhd }\end{array}$ & $\mathrm{L}$ & 14 & 0.7807 & 1 & 1 & 1 & 1 & 1 & 1 & 0.9687 \\
\hline $\begin{array}{l}\text { The Pacific } \\
\text { Insurance Bhd }\end{array}$ & $\mathrm{F}$ & 1 & 1 & 1 & 1 & 1 & 1 & 1 & 1 & 1 \\
\hline $\begin{array}{l}\text { Progressive } \\
\text { Insurance Bhd }\end{array}$ & $\mathrm{L}$ & 1 & 1 & 1 & 1 & 1 & 1 & 1 & 1 & 1 \\
\hline $\begin{array}{l}\text { QBE Insurance } \\
\text { Bhd }\end{array}$ & $\mathrm{F}$ & 1 & 1 & 1 & 1 & 1 & 1 & 1 & 1 & 1 \\
\hline $\begin{array}{l}\text { RHB Insurance } \\
\text { Bhd }\end{array}$ & $\mathrm{L}$ & 12 & 0.8738 & 1 & 1 & 1 & 1 & 0.9531 & 1 & 0.9753 \\
\hline $\begin{array}{l}\text { Tokio Marine } \\
\text { Insurans Bhd }\end{array}$ & $\mathrm{F}$ & 17 & 0.7318 & 0.9548 & 0.946 & 1 & 1 & 1 & 0.9649 & 0.9425 \\
\hline $\begin{array}{l}\text { Uni.Asia General } \\
\text { Insurance Bhd }\end{array}$ & $\mathrm{L}$ & 24 & 0.7646 & 0.7967 & 0.7565 & 0.8131 & 0.8219 & 0.8134 & 0.8872 & 0.8076 \\
\hline \multicolumn{11}{|c|}{ Composite Insurers } \\
\hline AIA Bhd & $\mathrm{F}$ & 10 & 1 & 1 & 0.9999 & 0.8469 & 0.9997 & 1 & 1 & 0.9781 \\
\hline $\begin{array}{l}\text { Etiqa Insurance } \\
\text { Bhd }\end{array}$ & $\mathrm{L}$ & 31 & 0.2609 & 0.4518 & 0.6686 & 0.7266 & 0.7437 & 0.6668 & 0.6645 & 0.5976 \\
\hline $\begin{array}{l}\text { MCIS Insurance } \\
\text { Bhd }\end{array}$ & $\mathrm{L}$ & 30 & 0.6596 & 0.197 & 0.6156 & 0.702 & 0.6866 & 0.72 & 0.6646 & 0.6065 \\
\hline $\begin{array}{l}\text { Prudential } \\
\text { Assurance } \\
\text { Malaysia Bhd }\end{array}$ & $\mathrm{F}$ & 8 & 0.9921 & 1 & 1 & 1 & 1 & 1 & 1 & 0.9989 \\
\hline $\begin{array}{l}\text { Zurich Insurance } \\
\text { Malaysia Berhad }\end{array}$ & F & 29 & 0.1649 & 0.7842 & 0.7518 & 0.7121 & 0.6874 & 0.6501 & 0.7029 & 0.6362 \\
\hline \multicolumn{11}{|c|}{ Life Insurers } \\
\hline $\begin{array}{l}\text { Allianz Life } \\
\text { Insurance } \\
\text { Malaysia Bhd }\end{array}$ & $\mathrm{F}$ & 1 & 1 & 1 & 1 & 1 & 1 & 1 & 1 & 1 \\
\hline $\begin{array}{l}\text { AmMetLife } \\
\text { insurance Bhd }\end{array}$ & $\mathrm{L}$ & 22 & 1 & 1 & 0.7763 & 0.8178 & 0.7491 & 1 & 0.6927 & 0.8623 \\
\hline $\begin{array}{l}\text { AXA Affin Life } \\
\text { Insurance Bhd }\end{array}$ & $\mathrm{L}$ & 27 & 1 & 0.6659 & 0.6631 & 0.6469 & 0.6982 & 0.8638 & 0.8429 & 0.7687 \\
\hline $\begin{array}{l}\text { Sun Life } \\
\text { Malaysia } \\
\text { Assurance Bhd }\end{array}$ & $\mathrm{L}$ & 26 & 0.5897 & 0.9462 & 0.6785 & 0.8535 & 0.7547 & 0.8228 & 0.8465 & 0.7846 \\
\hline $\begin{array}{l}\text { Great Eastern } \\
\text { Life Assurance } \\
\text { Bhd }\end{array}$ & $\mathrm{F}$ & 1 & 1 & 1 & 1 & 1 & 1 & 1 & 1 & 1 \\
\hline $\begin{array}{l}\text { Hong Leong } \\
\text { Assurance Bhd }\end{array}$ & $\mathrm{L}$ & 15 & 0.7589 & 1 & 1 & 1 & 1 & 1 & 1 & 0.9656 \\
\hline $\begin{array}{l}\text { Manulife } \\
\text { Insurance Bhd }\end{array}$ & $\mathrm{F}$ & 23 & 1 & 1 & 0.8053 & 0.9437 & 0.7203 & 0.7484 & 0.7805 & 0.8569 \\
\hline
\end{tabular}


End of Table 5

\begin{tabular}{|c|c|c|c|c|c|c|c|c|c|c|}
\hline Insurer & Ownership & Rank & 2008 & 2009 & 2010 & 2011 & 2012 & 2013 & 2014 & Average \\
\hline $\begin{array}{l}\text { Tokio Marine } \\
\text { Life Insurance } \\
\text { Bhd }\end{array}$ & $\mathrm{F}$ & 25 & 1 & 1 & 0.8158 & 0.7321 & 0.6382 & 0.6617 & 0.681 & 0.7898 \\
\hline $\begin{array}{l}\text { Gibraltar BSN } \\
\text { Life Bhd }\end{array}$ & $\mathrm{L}$ & 1 & 1 & 1 & 1 & 1 & 1 & 1 & 1 & 1 \\
\hline Average & & & 0.8294 & 0.8996 & 0.9005 & 0.9136 & 0.9098 & 0.9067 & 0.9108 & 0.8958 \\
\hline Average Foreign & & & 0.8714 & 0.9726 & 0.9438 & 0.9408 & 0.9258 & 0.9243 & 0.9378 & 0.9309 \\
\hline Average Local & & & 0.7948 & 0.8395 & 0.8649 & 0.8913 & 0.8966 & 0.8921 & 0.8885 & 0.8668 \\
\hline Average General & & & 0.8403 & 0.9319 & 0.9495 & 0.9613 & 0.9721 & 0.9396 & 0.9622 & 0.9367 \\
\hline $\begin{array}{l}\text { Average } \\
\text { Composite }\end{array}$ & & & 0.6155 & 0.6866 & 0.8072 & 0.7975 & 0.8235 & 0.8074 & 0.8064 & 0.7635 \\
\hline Average Life & & & 0.9276 & 0.9569 & 0.8599 & 0.8882 & 0.8401 & 0.8996 & 0.8715 & 0.8920 \\
\hline Max & & & 1 & 1 & 1 & 1 & 1 & 1 & 1 & 1 \\
\hline Min & & & 0.1649 & 0.197 & 0.6156 & 0.6469 & 0.6382 & 0.6501 & 0.6645 & 0.5976 \\
\hline SD & & & 0.2216 & 0.1884 & 0.1318 & 0.1145 & 0.1303 & 0.1275 & 0.1248 & 0.1225 \\
\hline No. efficient & & & 14 & 19 & 14 & 16 & 16 & 16 & 17 & 7 \\
\hline
\end{tabular}

Notes: $\mathrm{F}$ - foreign; L - local.

Table 6. Investment capability efficiency scores for Malaysian insurers

\begin{tabular}{|c|c|c|c|c|c|c|c|c|c|c|}
\hline Insurer & Ownership & Rank & 2008 & 2009 & 2010 & 2011 & 2012 & 2013 & 2014 & Average \\
\hline \multicolumn{11}{|c|}{ General insurers } \\
\hline $\begin{array}{l}\text { Allianz General } \\
\text { Insurance Co. } \\
\text { Bhd }\end{array}$ & $\mathrm{F}$ & 8 & 0.9994 & 0.9996 & 0.9999 & 0.8377 & 0.9999 & 0.9997 & 0.9999 & 0.9766 \\
\hline $\begin{array}{l}\text { AmGeneral } \\
\text { Insurance Bhd }\end{array}$ & $\mathrm{L}$ & 16 & 1 & 0.3952 & 0.6304 & 0.668 & 0.8309 & 0.9998 & 0.9996 & 0.7891 \\
\hline $\begin{array}{l}\text { AXA Affin } \\
\text { General } \\
\text { Insurance Bhd }\end{array}$ & $\mathrm{L}$ & 31 & 0.3832 & 0.348 & 0.4758 & 0.4311 & 0.5408 & 0.4844 & 0.607 & 0.4672 \\
\hline $\begin{array}{l}\text { Berjaya Sompo } \\
\text { Insurance Bhd }\end{array}$ & $\mathrm{L}$ & 30 & 0.432 & 0.3785 & 0.3591 & 0.5234 & 0.5451 & 0.5569 & 0.5982 & 0.4847 \\
\hline $\begin{array}{l}\text { AIG Malaysia } \\
\text { Insurance Bhd }\end{array}$ & $\mathrm{F}$ & 15 & 0.6206 & 0.712 & 0.8748 & 0.7487 & 0.8781 & 1 & 0.8526 & 0.8124 \\
\hline $\begin{array}{l}\text { Lonpac } \\
\text { Insurance } \\
\text { Berhad }\end{array}$ & $\mathrm{L}$ & 1 & 0.9999 & 1 & 1 & 1 & 1 & 1 & 1 & 1 \\
\hline $\begin{array}{l}\text { MSIG Insurance } \\
\text { Bhd }\end{array}$ & $\mathrm{F}$ & 7 & 1 & 0.9966 & 0.9996 & 0.9998 & 0.9998 & 0.9997 & 0.9998 & 0.9993 \\
\hline $\begin{array}{l}\text { Multi-Purpose } \\
\text { Insurans Bhd }\end{array}$ & $\mathrm{L}$ & 25 & 0.4828 & 0.4684 & 0.7537 & 0.6659 & 0.6933 & 0.6544 & 0.7075 & 0.6323 \\
\hline $\begin{array}{l}\text { Overseas } \\
\text { Assurance } \\
\text { Corporation Bhd }\end{array}$ & $\mathrm{F}$ & 14 & 0.5573 & 0.5574 & 0.8622 & 1 & 1 & 0.7973 & 1 & 0.8249 \\
\hline
\end{tabular}


Continue of Table 6

\begin{tabular}{|c|c|c|c|c|c|c|c|c|c|c|}
\hline Insurer & Ownership & Rank & 2008 & 2009 & 2010 & 2011 & 2012 & 2013 & 2014 & Average \\
\hline $\begin{array}{l}\text { Tune Insurance } \\
\text { Malaysia Bhd }\end{array}$ & $\mathrm{L}$ & 18 & 0.5191 & 0.6198 & 0.6075 & 0.7473 & 0.8123 & 0.9834 & 0.9884 & 0.754 \\
\hline $\begin{array}{l}\text { Pacific \& Orient } \\
\text { Insurance Co. } \\
\text { Bhd }\end{array}$ & $\mathrm{L}$ & 29 & 0.4026 & 0.4087 & 0.4544 & 0.5679 & 0.5275 & 0.5087 & 0.5998 & 0.4957 \\
\hline $\begin{array}{l}\text { The Pacific } \\
\text { Insurance Bhd }\end{array}$ & $\mathrm{F}$ & 21 & 0.4793 & 0.5863 & 0.6198 & 0.7211 & 0.8055 & 0.8204 & 1 & 0.7189 \\
\hline $\begin{array}{l}\text { Progressive } \\
\text { Insurance Bhd }\end{array}$ & $\mathrm{L}$ & 1 & 1 & 1 & 1 & 1 & 1 & 1 & 1 & 1 \\
\hline $\begin{array}{l}\text { QBE Insurance } \\
\text { Bhd }\end{array}$ & $\mathrm{F}$ & 6 & 0.9983 & 1 & 1 & 1 & 1 & 1 & 1 & 0.9998 \\
\hline $\begin{array}{l}\text { RHB Insurance } \\
\text { Bhd }\end{array}$ & $\mathrm{L}$ & 24 & 0.4886 & 0.5181 & 0.6178 & 0.6597 & 0.6795 & 0.6318 & 0.8325 & 0.6326 \\
\hline $\begin{array}{l}\text { Tokio Marine } \\
\text { Insurans Bhd }\end{array}$ & $\mathrm{F}$ & 27 & 0.3261 & 0.4006 & 0.4852 & 0.567 & 0.5869 & 0.6314 & 0.6997 & 0.5281 \\
\hline $\begin{array}{l}\text { Uni.Asia General } \\
\text { Insurance Bhd }\end{array}$ & $\mathrm{L}$ & 28 & 0.3339 & 0.3058 & 0.3384 & 0.5775 & 0.7165 & 0.6794 & 0.6572 & 0.5155 \\
\hline \multicolumn{11}{|c|}{ Composite Insurers } \\
\hline AIA Bhd & $\mathrm{F}$ & 1 & 1 & 1 & 1 & 1 & 1 & 1 & 1 & 1 \\
\hline $\begin{array}{l}\text { Etiqa Insurance } \\
\text { Bhd }\end{array}$ & $\mathrm{L}$ & 11 & 0.7775 & 0.8858 & 1 & 1 & 1 & 1 & 1 & 0.9519 \\
\hline $\begin{array}{l}\text { MCIS Insurance } \\
\text { Bhd }\end{array}$ & $\mathrm{L}$ & 17 & 1 & 0.8803 & 0.7668 & 0.5425 & 0.7414 & 0.7394 & 0.78 & 0.7786 \\
\hline $\begin{array}{l}\text { Prudential } \\
\text { Assurance } \\
\text { Malaysia Bhd }\end{array}$ & $\mathrm{F}$ & 1 & 0.9999 & 0.9999 & 0.9999 & 1 & 1 & 1 & 1 & 1 \\
\hline $\begin{array}{l}\text { Zurich Insurance } \\
\text { Malaysia Berhad }\end{array}$ & $\mathrm{F}$ & 20 & 0.6995 & 0.6333 & 0.5534 & 1 & 0.6575 & 0.8672 & 0.7079 & 0.7313 \\
\hline
\end{tabular}

Life Insurers

\begin{tabular}{|c|c|c|c|c|c|c|c|c|c|c|}
\hline $\begin{array}{l}\text { Allianz Life } \\
\text { Insurance } \\
\text { Malaysia Bhd }\end{array}$ & $\mathrm{F}$ & 26 & 0.6304 & 0.5785 & 0.5272 & 0.4253 & 0.6702 & 0.6218 & 0.5942 & 0.5782 \\
\hline $\begin{array}{l}\text { AmMetLife } \\
\text { insurance Bhd }\end{array}$ & $\mathrm{L}$ & 13 & 0.8043 & 0.6161 & 0.804 & 0.5767 & 1 & 1 & 1 & 0.8287 \\
\hline $\begin{array}{l}\text { AXA Affin Life } \\
\text { Insurance Bhd }\end{array}$ & $\mathrm{L}$ & 19 & 1 & 0.624 & 0.7094 & 0.832 & 0.6615 & 0.7297 & 0.6283 & 0.7407 \\
\hline $\begin{array}{l}\text { Sun Life } \\
\text { Malaysia } \\
\text { Assurance Bhd }\end{array}$ & $\mathrm{L}$ & 12 & 0.4695 & 0.6676 & 0.7279 & 1 & 1 & 1 & 1 & 0.8379 \\
\hline $\begin{array}{l}\text { Great Eastern } \\
\text { Life Assurance } \\
\text { Bhd }\end{array}$ & $\mathrm{F}$ & 1 & 1 & 1 & 1 & 1 & 1 & 1 & 1 & 1 \\
\hline $\begin{array}{l}\text { Hong Leong } \\
\text { Assurance Bhd }\end{array}$ & $\mathrm{L}$ & 10 & 0.895 & 1 & 1 & 1 & 1 & 0.9999 & 0.8142 & 0.9584 \\
\hline $\begin{array}{l}\text { Manulife } \\
\text { Insurance Bhd }\end{array}$ & $\mathrm{F}$ & 23 & 0.3207 & 0.7971 & 0.9516 & 0.7462 & 0.8232 & 0.6817 & 0.6513 & 0.7103 \\
\hline
\end{tabular}


End of Table 6

\begin{tabular}{lcccccccccc}
\hline \multicolumn{1}{c}{ Insurer } & Ownership & Rank & 2008 & 2009 & 2010 & 2011 & 2012 & 2013 & 2014 & Average \\
\hline $\begin{array}{l}\text { Tokio Marine } \\
\text { Life Insurance } \\
\text { Bhd }\end{array}$ & $\mathrm{F}$ & 22 & 0.7748 & 0.7282 & 0.7894 & 0.4685 & 0.7834 & 0.707 & 0.7354 & 0.7124 \\
\hline $\begin{array}{l}\text { Gibraltar BSN } \\
\text { Life Bhd }\end{array}$ & $\mathrm{L}$ & 9 & 0.7759 & 1 & 1 & 0.9999 & 1 & 1 & 1 & 0.968 \\
\hline Average & & 0.7152 & 0.7131 & 0.7712 & 0.7841 & 0.8372 & 0.8417 & 0.8533 & 0.7880 \\
\hline Average Foreign & & 0.7433 & 0.7850 & 0.8331 & 0.8225 & 0.8718 & 0.8662 & 0.8743 & 0.8280 \\
\hline Average Local & 0.6920 & 0.6539 & 0.7203 & 0.7525 & 0.8088 & 0.8216 & 0.8360 & 0.7550 \\
\hline Average General & & 0.6484 & 0.6291 & 0.7105 & 0.7479 & 0.8009 & 0.8087 & 0.8554 & 0.7430 \\
\hline $\begin{array}{l}\text { Average } \\
\text { Composite }\end{array}$ & & 0.8954 & 0.8799 & 0.8640 & 0.9085 & 0.8798 & 0.9213 & 0.8976 & 0.8924 \\
\hline Average Life & 0.7412 & 0.7791 & 0.8344 & 0.7832 & 0.8820 & 0.8600 & 0.8248 & 0.8150 \\
\hline Max & 1 & 1 & 1 & 1 & 1 & 1 & 1 & 1 \\
\hline Min & & 0.3207 & 0.3058 & 0.3384 & 0.4253 & 0.5275 & 0.4844 & 0.5942 & 0.4672 \\
\hline SD & 0.2572 & 0.2435 & 0.2207 & 0.2098 & 0.1702 & 0.1810 & 0.1648 & 0.1809 \\
\hline No. efficient & & 7 & 7 & 8 & 11 & 12 & 11 & 12 & 5 \\
\hline
\end{tabular}

Notes: F - foreign; L - local.

However, the types of insurers matter. Composite insurers present better investment abilities (89.24\%) than accumulating premiums (76.35\%), relative to the other two segments. As Table 7 shows, the efficiency scores of the composite segment statistically differ from the other two segments, which supports the conglomeration hypothesis (Cummins et al. 2010) when it comes to the investment capability function, and supports the strategic focus hypothesis (Cummins et al. 2010) when it comes to the premium accumulation function. This is a key advantage of the network structure, as one is able to extract the underlying reasons for the different types of inefficiencies.

Similar to the results for overall efficiency, foreign insurers are again statistically superior in both the premium accumulation and investment capability functions as compared to local insurers (see Table 7 for tests of differences).

\subsubsection{Comparing the results using different models}

While the insurance efficiency framework justifies the use of a DN-DEA model, this study compares the discriminating power and the average efficiency scores between various DEA models in Table 8. In the traditional models, CCR and Banker, Charnes and Cooper (BCC), and SBM, the carry-over and intermediate variables are removed. The intermediate variables in the DSBM model and the carry-over variables in the NSBM model are not included in the analyses. Within traditional models, CCR shows lower efficiency scores and less efficient DMUs, supporting the higher discriminating power of this model (Banker et al. 1984). However, the network idea introduced to reveal the underlying function of a production or service process, leads to higher discrimination power because it literally expands the sample through a factor of the number of processes in the framework (Kao 2009). 
Table 7. Tests of differences on efficiency scores by insurer and ownership types

\begin{tabular}{|c|c|c|c|c|c|}
\hline Characteristics & Classification & $\mathrm{N}$ & $\begin{array}{l}\text { Overall } \\
\text { Efficiency }\end{array}$ & $\begin{array}{c}\text { Premium Accumulation } \\
\text { Efficiency }\end{array}$ & $\begin{array}{c}\text { Investment Capability } \\
\text { Efficiency }\end{array}$ \\
\hline \multicolumn{6}{|c|}{ Mean efficiency (p-value) } \\
\hline \multirow{2}{*}{ Ownership } & Foreign & 98 & $\begin{array}{c}0.8475 \\
\left(0.002^{* * *}\right)\end{array}$ & $\begin{array}{c}0.9309 \\
\left(0.003^{* * *}\right)\end{array}$ & $\begin{array}{c}0.8280 \\
\left(0.053^{\star}\right)\end{array}$ \\
\hline & Local & 119 & $\begin{array}{c}0.7664 \\
\left(0.002^{\star * \star}\right)\end{array}$ & $\begin{array}{c}0.8668 \\
\left(0.003^{\star * *}\right) \\
\end{array}$ & $\begin{array}{c}0.7550 \\
\left(0.053^{\star}\right) \\
\end{array}$ \\
\hline \multirow{3}{*}{ Insurer } & General & 119 & $\begin{array}{l}0.8095 \\
(0.244) \\
\end{array}$ & $\begin{array}{c}0.9367 \\
\left(0.001^{* * *}\right) \\
\end{array}$ & $\begin{array}{c}0.7430 \\
\left(0.000^{* * *}\right) \\
\end{array}$ \\
\hline & Composite & 35 & $\begin{array}{l}0.8113 \\
(0.955) \\
\end{array}$ & $\begin{array}{c}0.7635 \\
\left(0.000^{* * *}\right) \\
\end{array}$ & $\begin{array}{c}0.8924 \\
\left(0.001^{* * *}\right) \\
\end{array}$ \\
\hline & Life & 63 & $\begin{array}{l}0.8395 \\
(0.218)\end{array}$ & $\begin{array}{l}0.8920 \\
(0.993)\end{array}$ & $\begin{array}{l}0.8149 \\
(0.131)\end{array}$ \\
\hline
\end{tabular}

Notes: ${ }^{\star} \mathrm{p}<0.1,{ }^{* *} \mathrm{p}<0.05,{ }^{* *} \mathrm{p}<0.01$.

On the other hand, the dynamic approach poorly performs in terms of discriminating the efficient insurers, where it has the highest number of efficient DMUs among all the models. However, with the inclusion of the dynamic structure in the network approach, the discriminating power lessens as compared to the network model, and is therefore far better than the dynamic model. As mentioned by Avkiran (2015), this issue warrants the dimensionality in an efficiency analysis with greater emphasis on input quantities.

Table 8. Comparison of efficiency scores between traditional and SBM models

\begin{tabular}{lccccccc}
\hline Models & 2008 & 2009 & 2010 & 2011 & 2012 & 2013 & 2014 \\
\hline CCR & $6(0.5986)$ & $8(0.6770)$ & $6(0.8189)$ & $5(0.8305)$ & $5(0.8175)$ & $5(0.8202)$ & $7(0.8406)$ \\
\hline BCC & $9(0.8080)$ & $12(0.8807)$ & $13(0.9153)$ & $9(0.8980)$ & $10(0.9090)$ & $16(0.9699)$ & $11(0.9491)$ \\
\hline SBM & $6(0.5180)$ & $12(0.7686)$ & $13(0.8074)$ & $9(0.8662)$ & $9(0.8005)$ & $16(0.9489)$ & $11(0.8413)$ \\
\hline DSBM & $11(0.7090)$ & $16(0.7801)$ & $17(0.8954)$ & $14(0.8730)$ & $14(0.9057)$ & $19(0.9398)$ & $11(0.9003)$ \\
\hline NSBM & $3(0.5446)$ & $6(0.6508)$ & $4(0.7424)$ & $7(0.7727)$ & $5(0.8241)$ & $6(0.7945)$ & $7(0.8358)$ \\
\hline DNSBM & $6(0.7332)$ & $8(0.7613)$ & $7(0.8116)$ & $8(0.8270)$ & $7(0.8612)$ & $10(0.8619)$ & $9(0.8727)$ \\
\hline
\end{tabular}

Notes: 1. Number of efficient insurers (average period efficiency score); 2. CCR and BCC are output oriented; 3. SBM, DSBM, NSBM, and DNSBM are non-oriented, VRS.

\subsection{Cluster analysis}

For multivariate data analysis, the cluster analysis has been identified as an effective tool for grouping objects (Jain 2010). It allows for a natural classification to identify the degree of similarity among objects. The cluster analysis goes through the data points by means of partitioning them into disjoint groups, in which the points fitting in the same cluster have similar attributes, while points fitting different clusters possess dissimilar attributes (Ding, He 2004). In fact, we perform the cluster analysis to have a better indication of the efficiencies of insurance companies by grouping them based on their three obtained efficiency scores. That is to say, we simultaneously include premium accumulation efficiency, 
investment capability efficiency and overall efficiency to obtain the location point for each insurer. Hence, a good performing insurance company must perform well in all three efficiency scores.

Using the cluster analysis, the study groups the insurers according to the efficiency scores obtained in the two functions and the overall efficiency. Two algorithm approaches are available in identifying the groups: hierarchy and partition. While the former finds a nested series of partitions to form a cluster hierarchy, the latter produces only one partition of the data without imposing a hierarchical structure (Jain et al. 1999). In a comprehensive review of the cluster analysis application, Punj and Stewart (1983) concluded that partition clustering algorithms are preferable to the hierarchical methods, however, the arbitrary number of output clusters may pose a problem (Punj, Stewart 1983). One can overcome this problem by running multiple algorithms with different numbers of clusters and selecting the best configuration obtained from all of the runs. The K-means has been known as the most reliable and popular partition method due to its simplicity, ease of implementation, empirical success and efficiency (Jain 2010; Punj, Stewart 1983). This study uses the $\mathrm{K}$-means analysis as described in Jain (2010).

Using the average efficiency scores for premium accumulation, investment capability and overall, we run a K-means cluster analysis to categorize the homogeneous insurers into different groups. This study executes the K-means cluster analysis using the Matlab Statistics Toolbox ${ }^{\mathrm{TM}}$. In doing so, this study uses the Euclidean distance function, which is the best method for computing the distance between objects and centroid ${ }^{2}$ (Hair et al. 2009). As mentioned above, the arbitrary number of clusters may be the most critical choice in performing K-means. Hence, we run the K-means for $k$ equals to 2, 3 and 4 clusters. In order to find the best solution, we computed the average silhouette values ${ }^{3}$ of all three possible options. The higher average silhouette values indicate a better cluster separation in that particular $k$ number of clusters. Consequently, the comparison shows that the 4-cluster algorithm provides us with higher average silhouette values ${ }^{4}(0.7040)$.

The K-means analysis categorizes the insurers into four groups, namely, top, middlehigh, middle-low and bottom clusters. Figure 3 illustrates the visual composition using the coordinates (average divisional efficiency and overall efficiency scores) of each insurer into a 3D plot. The cluster analysis assigned 10 insurers to the top cluster, eight insurers to the middle-high cluster, seven insurers to the middle-low cluster and six insurers to the bottom cluster.

Table 9 provides the average analysis of the clusters in accordance with insurer and ownership types. The top cluster consists of 10 insurers with an average overall efficiency of 98.90 percent, which is higher than the sectoral and other clusters' averages. This cluster takes the lead in the average divisional efficiency of sectorial and other clusters. The insurers in the middle-high cluster gained higher average efficiency in both premium accumulation division and overall efficiency, yet they achieved lower efficiency in the invest-

\footnotetext{
2 The centroid or centre point of a cluster is the average point of all the objects within a particular cluster.

${ }^{3}$ The silhouette value shows the similarity of each object relevant to its peers in its cluster compared to objects in neighbouring clusters.

${ }^{4}$ The average silhouette values for 2 -cluster and 3-cluster algorithms are 0.6327 and 0.6241 , respectively.
} 


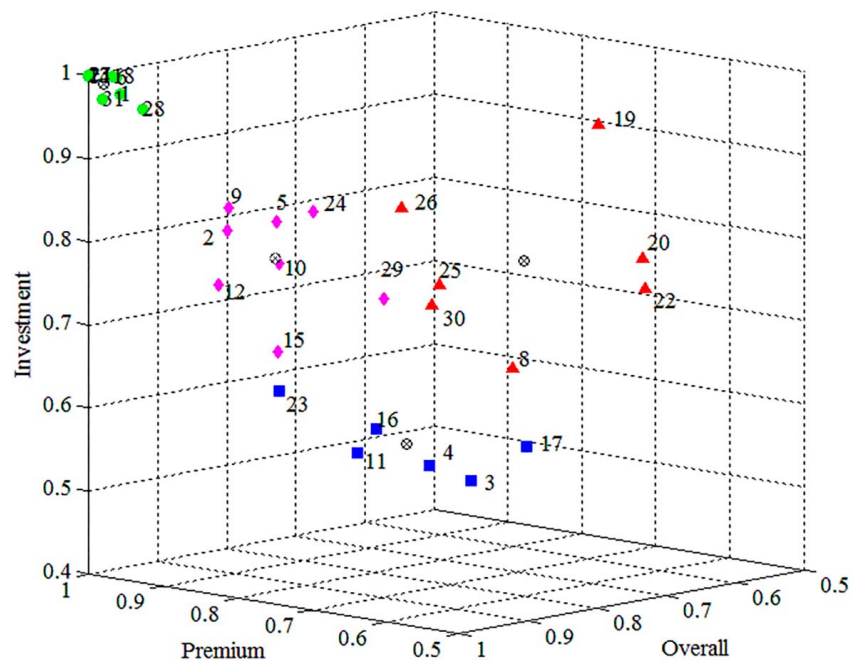

Figure 3. 3D plot for K-Means cluster analysis

Note: Four clusters are shown with circle (top), diamond (middle high), triangle (middle low), and square (bottom) colours. See Appendix Table A2, for insurers' codes.

ment capability division as compared to the insurers in the middle-low cluster. While the average premium accumulation of the six insurers in the bottom cluster is higher than the middle-low group, their investment capability efficiency and overall efficiency are lower than other clusters.

Table 9. K-Means clustering average of efficiencies, by insurer and ownership types

\begin{tabular}{ccccccc}
\hline \multirow{2}{*}{ Cluster } & Ownership & Insurer & $\begin{array}{c}\text { Premium } \\
\text { Accumulation }\end{array}$ & $\begin{array}{c}\text { Investment } \\
\text { Capability }\end{array}$ & Overall & No. of \\
& & & Insurers \\
\hline All & All & All & 0.8958 & 0.7880 & 0.8030 & 31 \\
\hline 1 (top) & All & All & 0.9897 & 0.9902 & 0.9890 & 10 \\
\hline 2 (middle-high) & All & All & 0.9313 & 0.7589 & 0.8027 & 8 \\
\hline 3 (middle-low) & All & All & 0.7038 & 0.7693 & 0.6863 & 7 \\
\hline 4 (bottom) & All & All & 0.9158 & 0.5116 & 0.6296 & 6 \\
\hline $1 \& 2$ & Foreign & All & 0.9665 & 0.9042 & 0.9185 & 10 \\
\hline $1 \& 2$ & Local & All & 0.9603 & 0.8664 & 0.8909 & 8 \\
\hline $3 \& 4$ & Foreign & All & 0.8421 & 0.6375 & 0.6701 & 4 \\
\hline $3 \& 4$ & Local & All & 0.7837 & 0.6561 & 0.6557 & 9 \\
\hline $1 \& 2$ & All & General & 0.9714 & 0.8643 & 0.8943 & 11 \\
\hline $1 \& 2$ & All & Composite & 0.6590 & 0.6667 & 0.6628 & 2 \\
\hline $1 \& 2$ & All & Life & 0.9370 & 0.8931 & 0.8973 & 5 \\
\hline $3 \& 4$ & All & General & 0.8731 & 0.5206 & 0.6193 & 6 \\
\hline $3 \& 4$ & All & Composite & 0.6134 & 0.8206 & 0.6318 & 3 \\
\hline $3 \& 4$ & All & Life & 0.8358 & 0.7173 & 0.7427 & 4 \\
\hline & & & & & &
\end{tabular}


Due to the few number of insurers in the sample, this study merged the top and middlehigh groups and also middle-low and bottom groups to provide more meaningful results. The results reveal that foreign insurers outstripped their local counterparts in divisional and overall efficiencies in clusters 1 and 2. However, within the lower clusters, local insurers managed their investment strategies better than foreign insurers. The total number of foreign insurers as compared to local insurers in the upper clusters (10 versus 8 ) signal the need for addressing efficiency among local companies. This finding is consistent with the results of superiority of foreign insurers in achieving higher periodic efficiency scores as compared to locals.

Among the top performers, general insurers acquired the highest premium accumulation efficiency, while life insurers outperformed the other segments in investment capability and overall efficiencies, and composite insurers remained in the middle. The same holds for general insurers in the weak performing group. Composite insurers did better, comparatively, in the investment capability division. The majority of general insurers found their place among good-performing clusters, but not composite insurers.

\subsection{Frontier projection analysis}

Through frontier projection analysis, this study also identifies the potential areas of improvements for the input, output, intermediate and carry-over variables, distinguished by year, insurer and ownership types. The aim is to derive the marginal contributions of a decrease in input amounts or an increase in output amounts in improving the efficiency scores. Table 10 provides the average excess (negative values) and shortage (positive value) of each variable.

To improve the premium accumulation efficiency, the insurers, on average, have to reduce business service expenses (X1) by 8.45 percent, debt capital (X2) by 9.73 percent and net claims (Z2) by 1.37 percent, and increase their equity capital (C1) and net premium earned (Z1) by 9.28 percent and 8.75 percent, respectively. Interestingly, the Malaysian insurance sector appears to better able to manage the intermediates, where the needs to increase net premium earned and to decrease the net claims become less important.

The main deficiency of local insurers in the premium accumulation function was due to excess usage of input quantities (consistent through the years), which is directly related to inadequate managerial abilities to allocate the resources in efficient manner. The excess usage of inputs is also the reason for the low efficiency of composite insurers relative to other segments. Nevertheless, composite insurers have suffered from the shortage of their net premium earned. There is another vital weakness within the composite segment. Composite insurers appear to waste their equity capital, particularly from 2012 to 2014, as opposed to the shortage of this carry-over item in the life and general segments.

The lack of total investment by local insurers can explain their low efficiency scores. On average, local insurers have to increase their investments by 77.15 percent. Their investment income must also increase by approximately the same percentage. Local insurers must restructure their investment policies and attract more foreign direct investment (FDI). 

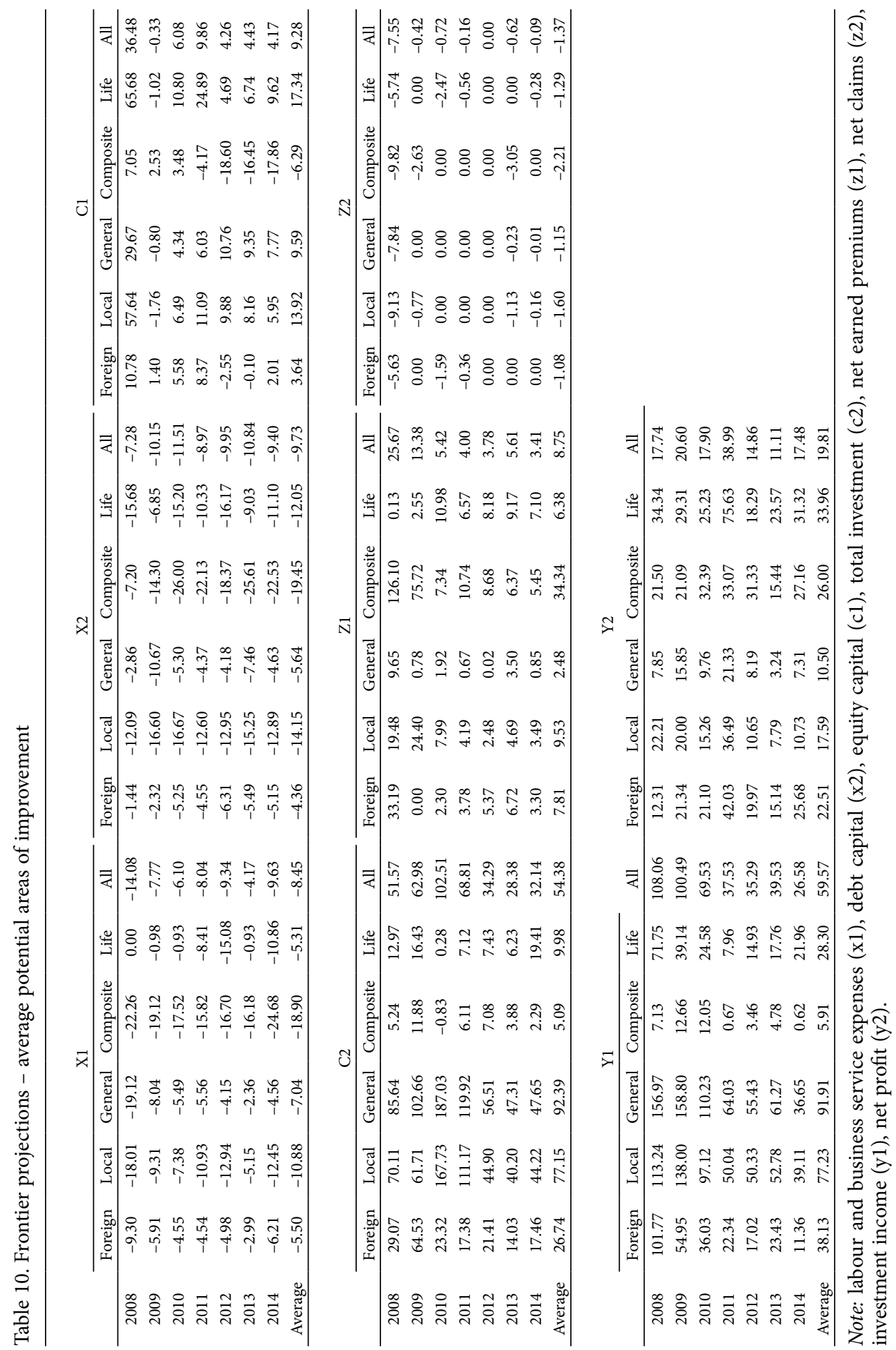
Specifically, the general segment suffered severely from shortage of total investment, at 92.39 percent on average, which in turn has significantly reduced its investment capability efficiency. Composite insurers, however, efficiently utilized their total investments and gained investment income, but they did not outperform in terms of net profit. In fact, increasing net profit should be the key concern for life and composite insurers, but not general insurers. The detailed suggestions for each insurance company to become efficient are provided in Appendix Table A2.

\section{Conclusions}

Based on the intermediation approach, this study proposed a new framework for performance efficiency to evaluate the business excellence of insurance companies. Following from the financial portfolio theory, the proposed framework disaggregated the service processes of insurance companies into two functions, namely, premium accumulation and investment capability. This study then applied the new framework to measure the efficiency of the Malaysian insurance companies across insurer and ownership types.

The results indicate lack of overall and divisional efficiencies among local insurers. The lack of overall efficiency is mainly due to the poor performance in the investment capability division. On average, life insurers stand above the average overall efficiency, while general insurers are superior in premium accumulation division, and composite insurers are better in investment capability division. The cluster analysis produces results that are largely consistent with the efficiency scores. Foreign insurers produce better average efficiency scores than their local counterparts in the top clusters, while the local insurers in the bottom clusters perform better in investments. The high number of local insurers among low performers calls for special attention for addressing inefficiencies of local insurers.

Finally, this study provides the potential areas of improvement for insurers to tackle the inefficiencies in their operating activities. Overuse of input resources are the major reasons for the low premium accumulation efficiencies of local insurers. In addition to the shortage of input quantities, the mismanagement of composite insurers to earn enough net premium and the wastage of equity capital are the reasons behind their inefficiencies in premium accumulation. To enhance the efficiency of investment capability, local insurers need to increase their total investments and subsequently investment income.

\section{Acknowledgements}

In completing this manuscript, we received helpful comments from Dr. Qian Long Kweh and Professor Wen-Min Lu. 


\section{References}

Arena, M. 2008. Does insurance market activity promote economic growth? A cross-country study for industrialized and developing countries, The Journal of Risk and Insurance 75(4): 921-946. https://doi.org/10.1111/j.1539-6975.2008.00291.x

Avkiran, N. K. 2009. Opening the black box of efficiency analysis: an illustration with UAE banks, Omega 37(4): 930-941. https://doi.org/10.1016/j.omega.2008.08.001

Avkiran, N. K. 2015. An illustration of dynamic network DEA in commercial banking including robustness tests, Omega 55: 141-150. https://doi.org/10.1016/j.omega.2014.07.002

Banker, R. D.; Charnes, A.; Cooper, W. W. 1984. Some models for estimating technical and scale inefficiencies in data envelopment analysis, Management Science 30(9): 1078-1092. https://doi.org/10.1287/mnsc.30.9.1078

Barros, C.; Wanke, P. 2016. Cost efficiency of African insurance companies using a finite mixture model, South African Journal of Economic and Management Sciences 19(1): 64-81. https://doi.org/10.4102/sajems.v19i1.1238

Barros, C. P.; Dumbo, S.; Wanke, P. 2014. Efficiency determinants and capacity issues in Angolan insurance companies, South African Journal of Economics 82(3): 455-467. https://doi.org/10.1111/saje.12056

Barros, C. P.; Wanke, P. 2014. Insurance companies in Mozambique: a two-stage DEA and neural networks on efficiency and capacity slacks, Applied Economics 46(29): 3591-3600.

Barros, C. P.; Wanke, P. 2015. Technology gaps and capacity issues in African insurance companies: selected country evidence, Journal of International Development 29(1): 117-133. https://doi.org/10.1002/jid.3098

Berger, A. N.; Humphrey, D. B. 1997. Efficiency of financial institutions: international survey and directions for future research, European Journal of Operational Research 98(2): 175-212. https://doi.org/10.1016/S0377-2217(96)00342-6

Biener, C.; Eling, M. 2012. Organization and efficiency in the international insurance industry: a crossfrontier analysis, European Journal of Operational Research 221(2): 454-468. https://doi.org/10.1016/j.ejor.2012.03.037

Biger, N.; Kahane, Y. 1978. Risk considerations in insurance ratemaking, The Journal of Risk and Insurance 45(1): 121-132. https://doi.org/10.2307/251812

Bjurek, H.; Hjalmarsson, L.; Forsund, F. R. 1990. Deterministic parametric and nonparametric estimation of efficiency in service production: a comparison, Journal of Econometrics 46(1): 213-227. https://doi.org/10.1016/0304-4076(90)90056-Y

Brockett, P. L.; Cooper, W. W.; Golden, L. L.; Rousseau, J. J.; Wang, Y. 2004. Evaluating solvency versus efficiency performance and different forms of organization and marketing in US property-liability insurance companies, European Journal of Operational Research 154(2): 492-514. https://doi.org/10.1016/S0377-2217(03)00184-X

Brockett, P. L.; Cooper, W. W.; Golden, L. L.; Rousseau, J. J.; Wang, Y. 2005. Financial intermediary versus production approach to efficiency of marketing distribution systems and organizational structure of insurance companies, The Journal of Risk and Insurance 72(3): 393-412. https://doi.org/10.1111/j.1539-6975.2005.00130.x

Charnes, A.; Cooper, W. W.; Rhodes, E. 1978. Measuring the efficiency of decision making units, European Journal of Operational Research 2(6): 429-444. https://doi.org/10.1016/0377-2217(78)90138-8

Chen, L.-R.; Lai, G. C.; Wang, J. L. 2011. Conversion and efficiency performance changes: evidence from the U.S. property-liability insurance industry, The Geneva Risk and Insurance Review 36(1): 1-35. https://doi.org/10.1057/grir.2010.3 
Choi, B. P.; Elyasiani, E. 2011. Foreign-owned insurer performance in the US property-liability markets, Applied Economics 43(3): 291-306. https://doi.org/10.1080/00036840802552353

Cooper, W. W.; Seiford, L. M.; Tone, K. 2007. Data envelopment analysis: a comprehensive text with models, applications, references and DEA-Solver software second edition. Springer US.

Cummins, J. D.; Rubio-Misas, M. 2006. Deregulation, consolidation, and efficiency: evidence from the Spanish insurance industry, Journal of Money, Credit, and Banking 38(2): 323-355. https://doi.org/10.1353/mcb.2006.0029

Cummins, J. D.; Turchetti, G.; Weiss, M. A. 1996. Productivity and technical efficiency in the Italian insurance industry. Wharton School Center for Financial Institutions, University of Pennsylvania, Working Paper.

Cummins, J. D.; Weiss, M. A. 2013. Analyzing firm performance in the insurance industry using frontier efficiency and productivity methods, Handbook of insurance. Springer.

Cummins, J. D.; Weiss, M. A.; Xie, X.; Zi, H. 2010. Economies of scope in financial services: a DEA efficiency analysis of the US insurance industry, Journal of Banking \& Finance 34(7): 1525-1539. https://doi.org/10.1016/j.jbankfin.2010.02.025

Cummins, J. D.; Weiss, M. A.; Zi, H. 1999. Organizational form and efficiency: the coexistence of stock and mutual property-liability insurers, Management Science 45(9): 1254-1269. https://doi.org/10.1287/mnsc.45.9.1254

Cummins, J. D.; Xie, X. 2008. Mergers and acquisitions in the US property-liability insurance industry: productivity and efficiency effects, Journal of Banking \& Finance 32(1): 30-55. https://doi.org/10.1016/j.jbankfin.2007.09.003

Cummins, J. D.; Zi, H. 1998. Measuring economic efficiency of the US life insurance industry: econometric and mathematical programming techniques, Journal of Productivity Analysis 10: 131-145. https://doi.org/10.1023/A:1026402922367

Ding, C.; He, X. 2004. K-means clustering via principal component analysis, in Proceedings of The Twenty-First International Conference on Machine Learning, 4-8 July 2004, Banff, Alberta, Canada, 29. https://doi.org/10.1145/1015330.1015408

Doherty, N. A. 1980. A portfolio theory of insurance capacity, The Journal of Risk and Insurance 47(3): 405-420. https://doi.org/10.2307/252630

Du, J.; Wang, J.; Chen, Y.; Chou, S.-Y.; Zhu, J. 2014. Incorporating health outcomes in Pennsylvania hospital efficiency: an additive super-efficiency DEA approach, Annals of Operations Research 221(1): 161-172. https://doi.org/10.1007/s10479-011-0838-y

Eling, M.; Luhnen, M. 2010a. Efficiency in the international insurance industry: a cross-country comparison, Journal of Banking \& Finance 34(7): 1497-1509.

https://doi.org/10.1016/j.jbankfin.2009.08.026

Eling, M.; Luhnen, M. 2010b. Frontier efficiency methodologies to measure performance in the insurance industry: overview, systematization, and recent developments, The Geneva Papers on Risk and Insurance - Issues and Practice 35(2): 217-265. https://doi.org/10.1057/gpp.2010.1

Färe, R.; Grosskopf, S.; Whittaker, G. 2007. Network DEA, Chapter 12 in J. Zhu, W. Cook (Eds.). Modeling Data Irregularities and Structural Complexities in Data Envelopment Analysis. Springer US. https://doi.org/10.1007/978-0-387-71607-7_12

Färe, R.; Whittaker, G. 1995. An intermediate input model of dairy production using complex survey data, Journal of Agricultural Economics 46(2): 201-213. https://doi.org/10.1111/j.1477-9552.1995.tb00766.x

Farrell, M. J. 1957. The measurement of productive efficiency, Journal of the Royal Statistical Society. Series A (General) 120(3): 253-290. https://doi.org/10.2307/2343100

Fecher, F.; Pestieau, P. 1993. Efficiency and competition in OECD financial services, The Measurement of Productive Efficiency: 374-385. 
Golany, B.; Roll, Y. 1989. An application procedure for DEA, Omega 17(3): 237-250. https://doi.org/10.1016/0305-0483(89)90029-7

Hair, J. F.; Black, W. C.; Babin, B. J.; Anderson, R. E. 2009. Cluster analysis, Chapter 9 in Multivariate Data Analysis. 7th ed. Prentice-Hall.

Haugen, R. A.; Kroncke, C. O. 1970. A portfolio approach to optimizing the structure of capital claims and assets of a stock insurance company, The Journal of Risk and Insurance 37(1): 41-48. https://doi.org/10.2307/251517

Huang, L.-Y.; Ma, Y.-L.; Pope, N. 2012. Foreign ownership and non-life insurer efficiency in the Japanese marketplace, Risk Management and Insurance Review 15(1): 57-88.

https://doi.org/10.1111/j.1540-6296.2011.01202.x

Huang, W.; Eling, M. 2013. An efficiency comparison of the non-life insurance industry in the BRIC countries, European Journal of Operational Research 226(3): 577-591. https://doi.org/10.1016/j.ejor.2012.11.008

Hwang, S.-N.; Kao, T.-L. 2008. Using two-stage DEA to measure managerial efficiency change of nonlife insurance companies in Taiwan, International Journal of Management and Decision Making 9(4): 377-401. https://doi.org/10.1504/IJMDM.2008.019362

Jain, A. K. 2010. Data clustering: 50 years beyond K-means, Pattern Recognition Letters 31(8): 651-666. https://doi.org/10.1016/j.patrec.2009.09.011

Jain, A. K.; Murty, M. N.; Flynn, P. J. 1999. Data clustering: a review, ACM computing surveys (CSUR) 31(3): 264-323.

Kao, C. 2009. Efficiency decomposition in network data envelopment analysis: a relational model, European Journal of Operational Research 192(3): 949-962. https://doi.org/10.1016/j.ejor.2007.10.008

Kao, C.; Hwang, S.-N. 2008. Efficiency decomposition in two-stage data envelopment analysis: an application to non-life insurance companies in Taiwan, European Journal of Operational Research 185(1): 418-429. https://doi.org/10.1016/j.ejor.2006.11.041

Kuo, K.-C.; Kweh, Q. L.; Ting, I. W. K.; Azizan, N. A. 2017. Dynamic network performance evaluation of general insurance companies: an insight into risk management committee structure, Total Quality Management \& Business Excellence 28(5-6): 542-558. https://doi.org/10.1080/14783363.2015.1100516

Kweh, Q. L.; Lu, W.-M.; Wang, W.-K. 2014a. Dynamic efficiency: intellectual capital in the Chinese non-life insurance firms, Journal of Knowledge Management 18(5): 937-951. https://doi.org/10.1108/JKM-06-2014-0240

Kweh, Q. L.; Lu, W.-M.; Wang, W.-K.; Su, M.-H. 2014b. Life insurance companies' performance and intellectual capital: a long-term perspective, International Journal of Information Technology \& Decision Making 13(4): 755-777. https://doi.org/10.1142/S0219622014500588

Liu, J. S.; Lu, L. Y.; Lu, W.-M.; Lin, B. J. 2013. A survey of DEA applications, Omega 41(5): 893-902. https://doi.org/10.1016/j.omega.2012.11.004

Lu, W.-M.; Kweh, Q. L.; Nourani, M.; Huang, F.-W. 2016. Evaluating the efficiency of dual-use technology development programs from the R\&D and socio-economic perspectives, Omega 62: 82-92. https://doi.org/10.1016/j.omega.2015.08.011

Lu, W.-M.; Wang, W.-K.; Kweh, Q. L. 2014. Intellectual capital and performance in the Chinese life insurance industry, Omega 42(1): 65-74. https://doi.org/10.1016/j.omega.2013.03.002

Macminn, R. D.; Witt, R. C. 1987. A financial theory of the insurance firm under uncertainty and regulatory constraints, The Geneva Papers on Risk and Insurance - Issues and Practice: 12(1): 3-20. https://doi.org/10.1057/gpp.1987.1

Mahajan, J. 1991. A data envelopment analytic model for assessing the relative efficiency of the selling function, European Journal of Operational Research 53(2): 189-205.

https://doi.org/10.1016/0377-2217(91)90134-H 
Müller, W. 1981. Theoretical concepts of insurance production, The Geneva Papers on Risk and Insurance - Issues and Practice: 6(4): 63-83. https://doi.org/10.1057/gpp.1981.23

Nourani, M.; Devadason, E. S.; Kweh, Q. L.; Lu, W.-M. 2017. Business excellence: the managerial and value-creation efficiencies of the insurance companies, Total Quality Management \& Business Excellence: 28(7-8): 879-896. https://doi.org/10.1080/14783363.2015.1133244

Pfeffer, I.; Klock, D. R. 1974. Perspectives on insurance. Prentice-Hall.

Punj, G.; Stewart, D. W. 1983. Cluster analysis in marketing research: review and suggestions for application, Journal of Marketing Research: 20(2): 134-148. https://doi.org/10.2307/3151680

Tone, K. 2001. A slacks-based measure of efficiency in data envelopment analysis, European Journal of Operational Research 130(3): 498-509. https://doi.org/10.1016/S0377-2217(99)00407-5

Tone, K.; Tsutsui, M. 2009. Network DEA: a slacks-based measure approach, European Journal of Operational Research 197(1): 243-252. https://doi.org/10.1016/j.ejor.2008.05.027

Tone, K.; Tsutsui, M. 2010. Dynamic DEA: a slacks-based measure approach, Omega 38(3): 145-156. https://doi.org/10.1016/j.omega.2009.07.003

Tone, K.; Tsutsui, M. 2014. Dynamic DEA with network structure: a slacks-based measure approach, Omega 42(1): 124-131. https://doi.org/10.1016/j.omega.2013.04.002

Trowbridge, C. L. 1975. Insurance as a transfer mechanism, The Journal of Risk and Insurance 42(1): 1-15. https://doi.org/10.2307/251584

Von Lanzenauer, C. H.; Wright, D. D. 1977. Optimizing claims fluctuation reserves, Management Science: 23(11): 1199-1207. https://doi.org/10.1287/mnsc.23.11.1199

Wanke, P.; Azad, M. A. K.; Barros, C. P. 2016. Financial distress and the Malaysian dual baking system: a dynamic slacks approach, Journal of Banking \& Finance 66: 1-18. https://doi.org/10.1016/j.jbankfin.2016.01.006

Wanke, P.; Barros, C. P. 2016. Efficiency drivers in Brazilian insurance: a two-stage DEA meta frontierdata mining approach, Economic Modelling 53: 8-22. https://doi.org/10.1016/j.econmod.2015.11.005

Wanke, P.; Barros, C. P.; Faria, J. R. 2015. Financial distress drivers in Brazilian banks: a dynamic slacks approach, European Journal of Operational Research 240(1): 258-268. https://doi.org/10.1016/j.ejor.2014.06.044

Wu, Y.-C.; Ting, I. W. K.; Lu, W.-M.; Nourani, M.; Kweh, Q. L. 2016. The impact of earnings management on the performance of ASEAN banks, Economic Modelling 53: 156-165. https://doi.org/10.1016/j.econmod.2015.11.023

Xie, X. 2010. Are publicly held firms less efficient? Evidence from the US property-liability insurance industry, Journal of Banking \& Finance 34(7): 1549-1563. https://doi.org/10.1016/j.jbankfin.2010.01.007

Zhu, J. 2014. Quantitative models for performance evaluation and benchmarking: data envelopment analysis with spreadsheets. Springer US. https://doi.org/10.1007/978-3-319-06647-9 


\section{APPENDIX}

Table A1. Yearly summary statistics of the input, carry-over, intermediate, and output variables

\begin{tabular}{|c|c|c|c|c|c|c|c|c|}
\hline & \multicolumn{4}{|c|}{ Panel A: Year 2008} & \multicolumn{4}{|c|}{ Panel B: Year 2009} \\
\hline & Mean & Median & SD & Range & Mean & Median & Std. Dev. & Range \\
\hline $\begin{array}{l}\text { Labor and business service expenses } \\
\left(\mathrm{X}_{1}\right)\end{array}$ & 70732 & 58348 & 59154 & 290060 & 83425 & 55397 & 74386 & 276658 \\
\hline Debt capital $\left(\mathrm{X} 2_{\mathrm{t}}\right)$ & 1122382 & 503803 & 1358305 & 4988548 & 3109898 & 717320 & 7889220 & 43322657 \\
\hline Equity capital $\left(\mathrm{Cl}_{\mathrm{t}-1}\right)$ & 407124 & 238595 & 753018 & 4313728 & 594058 & 314137 & 929213 & 4516512 \\
\hline Investment assets $\left(\mathrm{C} 2_{\mathrm{t}-1}\right)$ & 320901 & 158467 & 511364 & 2561933 & 572215 & 265177 & 971587 & 4320784 \\
\hline Net earned premiums $\left(\mathrm{Z} 1_{\mathrm{t}}\right)$ & 360626 & 217882 & 378559 & 1692076 & 302920 & 236075 & 234779 & 922093 \\
\hline Net claims $\left(Z 2_{t}\right)$ & 2592949 & 726254 & 5433726 & 28644731 & 2787948 & 768625 & 6398622 & 34497267 \\
\hline Investment income $\left(\mathrm{Y} 1_{\mathrm{t}}\right)$ & 151059 & 31396 & 351527 & 1813560 & 158273 & 34938 & 328354 & 1660135 \\
\hline \multirow[t]{2}{*}{ Net profit $\left(\mathrm{Y} 2_{\mathrm{t}}\right)$} & 50043 & 21754 & 91693 & 420040 & 74164 & 29887 & 117528 & 520437 \\
\hline & \multicolumn{4}{|c|}{ Panel C: Year 2010} & \multicolumn{4}{|c|}{ Panel D: Year 2011} \\
\hline $\begin{array}{l}\text { Labor and business service expenses } \\
\left(\mathrm{X}_{1}\right)\end{array}$ & 96521 & 69736 & 82528 & 292268 & 102689 & 79286 & 85349 & 330580 \\
\hline Debt capital $\left(\mathrm{X} 2_{\mathrm{t}}\right)$ & 4613615 & 1086200 & 9365274 & 48244599 & 4750006 & 1225018 & 9650944 & 50563101 \\
\hline Equity capital $\left(\mathrm{Cl}_{\mathrm{t}-1}\right)$ & 809637 & 456497 & 1100881 & 5203719 & 852061 & 476554 & 1171990 & 5446393 \\
\hline Investment assets $\left(\mathrm{C} 2_{\mathrm{t}-1}\right)$ & 782523 & 358762 & 1339540 & 6671928 & 760733 & 340165 & 1298594 & 6644728 \\
\hline Net earned premiums $\left(\mathrm{Zl}_{\mathrm{t}}\right)$ & 381875 & 223262 & 309581 & 997164 & 478984 & 292206 & 433117 & 1736094 \\
\hline Net claims $\left(\mathrm{Z}_{\mathrm{t}}\right)$ & 3356575 & 836859 & 7953285 & 42691761 & 4193559 & 953953 & 9049143 & 47277735 \\
\hline Investment income $\left(\mathrm{Y}_{\mathrm{t}}\right)$ & 180533 & 39711 & 362998 & 1841422 & 190070 & 57476 & 384956 & 1991438 \\
\hline \multirow[t]{2}{*}{ Net profit $\left(\mathrm{Y} 2_{\mathrm{t}}\right)$} & 87062 & 39124 & 117986 & 453717 & 104272 & 38529 & 183296 & 986693 \\
\hline & \multicolumn{4}{|c|}{ Panel E: Year 2012} & \multicolumn{4}{|c|}{ Panel E: Year 2013} \\
\hline $\begin{array}{l}\text { Labor and business service expenses } \\
\left(\mathrm{X}_{\mathrm{t}}\right)\end{array}$ & 119823 & 88044 & 96297 & 358051 & 139273 & 103159 & 129027 & 493075 \\
\hline Debt capital $\left(\mathrm{X} 2_{\mathrm{t}}\right)$ & 5102743 & 1657982 & 10500363 & 55344423 & 5906226 & 1489766 & 11962851 & 57639882 \\
\hline Equity capital $\left(\mathrm{Cl}_{\mathrm{t}-1}\right)$ & 933327 & 481246 & 1276904 & 5673224 & 1057994 & 542402 & 1430121 & 5866297 \\
\hline Investment assets $\left(\mathrm{C} 2_{\mathrm{t}-1}\right)$ & 886335 & 361685 & 1595035 & 7912758 & 859655 & 399622 & 1286004 & 5494705 \\
\hline Net earned premiums $\left(\mathrm{Z}_{\mathrm{t}}\right)$ & 583568 & 383686 & 543009 & 2336241 & 682939 & 436132 & 591486 & 2330200 \\
\hline Net claims $\left(\mathrm{Z}_{\mathrm{t}}\right)$ & 4433531 & 1022835 & 9492012 & 49980024 & 4912199 & 1167710 & 10431221 & 54824541 \\
\hline Investment income $\left(\mathrm{Y} 1_{\mathrm{t}}\right)$ & 214095 & 58126 & 431783 & 2238195 & 237783 & 57145 & 481423 & 2409070 \\
\hline $\operatorname{Net}$ profit $\left(\mathrm{Y}_{\mathrm{t}}\right)$ & 109950 & 51508 & 139260 & 552927 & 129713 & 64319 & 164546 & 665564 \\
\hline \multicolumn{9}{|c|}{ Panel F: Year 2014} \\
\hline $\begin{array}{l}\text { Labor and business service expenses } \\
\left(\mathrm{X}_{\mathrm{t}}\right)\end{array}$ & 142383 & 97979 & 131598 & 614873 & & & & \\
\hline Debt capital $\left(\mathrm{X} 2_{\mathrm{t}}\right)$ & 6165685 & 1577694 & 12355868 & 58797060 & & & & \\
\hline Equity capital $\left(\mathrm{Cl}_{\mathrm{t}-1}\right)$ & 1152941 & 505216 & 1621623 & 6284588 & & & & \\
\hline Investment assets $\left(\mathrm{C} 2_{\mathrm{t}-1}\right)$ & 969030 & 320391 & 1611906 & 6691649 & & & & \\
\hline Net earned premiums $\left(Z 1_{t}\right)$ & 791751 & 421287 & 787131 & 3560080 & & & & \\
\hline Net claims $\left(\mathrm{Z2}_{\mathrm{t}}\right)$ & 5688714 & 1333350 & 11784214 & 57214469 & & & & \\
\hline Investment income $\left(\mathrm{Y} 1_{\mathrm{t}}\right)$ & 254389 & 65504 & 519399 & 2438425 & & & & \\
\hline Net profit $\left(\mathrm{Y} 2_{\mathrm{t}}\right)$ & 131345 & 67143 & 166306 & 699131 & & & & \\
\hline
\end{tabular}


Table A2. Frontier projections - potential areas for improvement, 2008-2014

\begin{tabular}{|c|c|c|c|c|c|c|c|c|c|c|}
\hline Insurer & No. & Ownership & $\mathrm{X} 1$ & $\mathrm{X} 2$ & $\mathrm{C} 1$ & $\mathrm{C} 2$ & $\mathrm{Z1}$ & $\mathrm{Z} 2$ & Y1 & Y2 \\
\hline \multicolumn{11}{|c|}{ General Insurers } \\
\hline Allianz General Insurance Co. Bhd & 1 & $\mathrm{~F}$ & 0.22 & 0.03 & -5.78 & -0.02 & 2.93 & 2.65 & 0.00 & -0.32 \\
\hline AmGeneral Insurance Bhd & 2 & $\mathrm{~L}$ & 0.82 & 11.52 & -3.89 & -0.17 & 61.70 & 18.81 & 1.04 & 0.00 \\
\hline AXA Affin General Insurance Bhd & 3 & $\mathrm{~L}$ & 37.95 & 392.75 & -20.43 & -11.52 & 205.45 & 36.43 & 1.64 & -2.58 \\
\hline Berjaya Sompo Insurance Bhd & 4 & $\mathrm{~L}$ & 13.92 & 138.31 & -4.46 & -7.96 & 207.99 & 19.27 & 7.53 & -0.59 \\
\hline AIG Malaysia Insurance Bhd & 5 & $\mathrm{~F}$ & -0.60 & 29.62 & -12.79 & -0.47 & 33.28 & 18.33 & 9.37 & 0.00 \\
\hline Lonpac Insurance Berhad & 6 & $\mathrm{~L}$ & 0.00 & 0.00 & -5.77 & -1.75 & 0.00 & 0.00 & 0.00 & 0.00 \\
\hline MSIG Insurance Bhd & 7 & $\mathrm{~F}$ & 0.00 & 0.07 & 0.00 & 0.00 & 0.13 & 0.01 & 0.00 & 0.00 \\
\hline Multi-Purpose Insurans Bhd & 8 & $\mathrm{~L}$ & 93.67 & 68.02 & -17.96 & -36.88 & 115.67 & 10.58 & 7.06 & -8.75 \\
\hline Overseas Assurance Corporation Bhd & 9 & $\mathrm{~F}$ & -1.60 & 6.79 & -6.79 & -3.95 & 55.21 & 2.00 & 1.08 & -1.89 \\
\hline Tune Insurance Malaysia Bhd & 10 & $\mathrm{~L}$ & -2.32 & 19.32 & -2.68 & -9.67 & 73.61 & 5.93 & 4.41 & 0.00 \\
\hline Pacific \& Orient Insurance Co. Bhd & 11 & $\mathrm{~L}$ & 0.00 & 300.87 & -3.54 & 0.00 & 196.67 & 15.37 & 2.00 & -1.18 \\
\hline The Pacific Insurance Bhd & 12 & $\mathrm{~F}$ & 0.00 & 45.67 & 0.00 & 0.00 & 88.90 & 4.04 & 0.00 & 0.00 \\
\hline Progressive Insurance Bhd & 13 & $\mathrm{~L}$ & 0.00 & 0.00 & 0.00 & 0.00 & 0.00 & 0.00 & 0.00 & 0.00 \\
\hline QBE Insurance Bhd & 14 & $\mathrm{~F}$ & 0.00 & 0.00 & 0.00 & 0.00 & 0.05 & 0.00 & 0.00 & 0.00 \\
\hline RHB Insurance Bhd & 15 & $\mathrm{~L}$ & 0.00 & 51.70 & -3.30 & -4.12 & 120.80 & 3.96 & 0.00 & 0.00 \\
\hline Tokio Marine Insurans Bhd & 16 & $\mathrm{~F}$ & 3.74 & 209.91 & -11.59 & -3.62 & 185.60 & 17.40 & 0.00 & -2.04 \\
\hline Uni.Asia General Insurance Bhd & 17 & $\mathrm{~L}$ & 17.22 & 296.04 & -20.68 & -15.74 & 214.52 & 23.79 & 8.09 & -2.28 \\
\hline \multicolumn{11}{|c|}{ Composite Insurers } \\
\hline AIA Bhd & 18 & $\mathrm{~F}$ & -0.01 & 0.00 & -2.44 & -4.14 & 0.00 & 0.00 & 0.00 & 0.00 \\
\hline Etiqa Insurance Bhd & 19 & $\mathrm{~L}$ & -57.09 & -0.91 & -42.54 & -33.70 & 5.19 & 6.68 & 45.42 & -1.88 \\
\hline MCIS Insurance Bhd & 20 & $\mathrm{~L}$ & 4.42 & -0.97 & -19.54 & -37.03 & 4.83 & 59.93 & 58.91 & -2.18 \\
\hline Prudential Assurance Malaysia Bhd & 21 & $\mathrm{~F}$ & 0.00 & 0.01 & 0.00 & 0.00 & 0.01 & 0.00 & 0.11 & 0.00 \\
\hline Zurich Insurance Malaysia Berhad & 22 & $\mathrm{~F}$ & 21.24 & 27.33 & -29.95 & -22.38 & 19.53 & 63.39 & 67.27 & -7.01 \\
\hline \multicolumn{11}{|c|}{ Life Insurers } \\
\hline Allianz Life Insurance Malaysia Bhd & 23 & $\mathrm{~F}$ & 0.00 & 36.85 & 0.00 & 0.00 & 62.77 & 89.97 & 0.00 & 0.00 \\
\hline AmMetLife insurance Bhd & 24 & $\mathrm{~L}$ & 35.10 & -1.51 & -17.54 & -17.22 & 17.23 & 35.47 & 2.73 & 0.00 \\
\hline AXA Affin Life Insurance Bhd & 25 & $\mathrm{~L}$ & 14.70 & 22.57 & -10.38 & -19.29 & 50.65 & 26.14 & 18.44 & -0.35 \\
\hline Sun Life Malaysia Assurance Bhd & 26 & $\mathrm{~L}$ & 78.30 & 8.27 & -12.29 & -35.57 & 27.68 & 29.52 & 4.61 & -7.38 \\
\hline Great Eastern Life Assurance Bhd & 27 & $\mathrm{~F}$ & 0.00 & 0.00 & 0.00 & 0.00 & 0.00 & 0.00 & 0.00 & 0.00 \\
\hline Hong Leong Assurance Bhd & 28 & $\mathrm{~L}$ & 0.00 & 5.56 & 0.00 & -9.95 & 6.20 & 3.67 & 0.17 & 0.00 \\
\hline Manulife Insurance Bhd & 29 & $\mathrm{~F}$ & -7.28 & 19.20 & 0.00 & -5.53 & 80.01 & 33.70 & 16.00 & -0.72 \\
\hline Tokio Marine Life Insurance Bhd & 30 & $\mathrm{~F}$ & 35.25 & -1.11 & -7.60 & -20.91 & 5.38 & 83.64 & 15.48 & -3.17 \\
\hline Gibraltar BSN Life Bhd & 31 & $\mathrm{~L}$ & 0.00 & 0.00 & 0.00 & 0.00 & 4.75 & 3.50 & 0.00 & 0.00 \\
\hline
\end{tabular}

